\title{
Data report: bulk carbonate content of sediments and mineralogy of authigenic carbonates along an east-west transect in the northern Cascadia margin, IODP Expedition $311^{1}$
}

Marie-Madeleine Blanc-Valleron, ${ }^{2}$ Catherine Pierre, ${ }^{3}$ Danièle Bartier, ${ }^{2}$ and Jean-Marie Rouchy ${ }^{2}$

\section{Chapter contents}

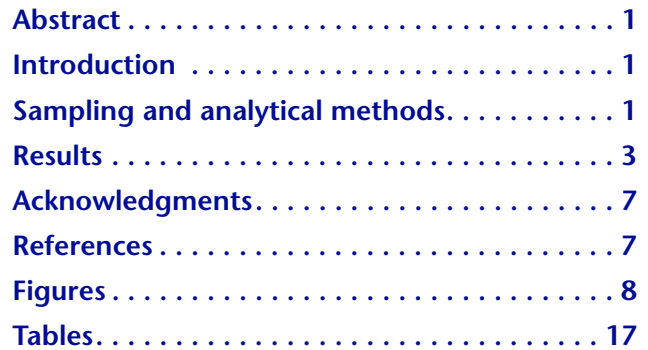

${ }^{1}$ Blanc-Valleron, M.-M., Pierre, C., Bartier, D., and Rouchy, J.-M., 2009. Data report: bulk carbonate content of sediments and mineralogy of authigenic carbonates along an east-west transect in the northern Cascadia margin, IODP Expedition 311. In Riedel, M., Collett, T.S., Malone, M.J., and the Expedition 311 Scientists, Proc. IODP, 311: Washington, DC (Integrated Ocean Drilling Program Management International, Inc.). doi:10.2204/iodp.proc.311.204.2009 2UMR 5143 CNRS, Département Histoire de la Terre-Géologie, Muséum National d'Histoire Naturelle (MNHN), 43 rue Buffon, 75005 Paris, France. Correspondence author:

valleron@mnhn.fr

${ }^{3}$ CNRS-LOCEAN, Université Pierre et Marie Curie, 4 place Jussieu, 75252 Paris Cedex 5, France.

\begin{abstract}
Carbonate content and mineralogical composition of sediment samples from Integrated Ocean Drilling Program Sites U1325U1329 in the northern Cascadia margin were determined. The results document their low carbonate content (average $\approx 2-3 \mathrm{wt} \%$ ), with decreasing values with distance to the shoreline. Carbonate content and carbonate mineralogy (calcite, dolomite, aragonite, siderite, and rhodochrosite) of 85 authigenic carbonate samples were also determined.
\end{abstract}

\section{Introduction}

This report presents the results of X-ray diffraction (XRD) and carbonatometry analyses of samples from five sites cored during Integrated Ocean Drilling Program (IODP) Expedition 311 (see the "Expedition 311 summary" chapter). Sites U1325-U1327 and U1329 are located along a southwest-northeast transect across the Cascadia margin, whereas Site U1328 corresponds to an active seafloor seepage near Site U1327 (Fig. F1).

Authigenic carbonates have been previously recognized at the Cascadia margin (e.g., Sample and Kopf, 1995; Bohrmann et al., 1998; Greinert et al., 2001; Teichert et al., 2005; Teichert and Bohrmann, 2006) and may help evaluate the environmental conditions (i.e., temperature and geochemistry of pore fluids) during carbonate formation.

\section{Sampling and analytical methods}

During Expedition 311, >500 samples of standard sediments (SED), usually one per section $(\sim 75-77 \mathrm{~cm})$ regardless of facies sand or clay, and 85 samples (CARB) of semi-indurated sediments $(<10 \%$ carbonate cement and mostly lighter color than the surrounding sediments), small concretions, or hard rock pieces were collected from several sites.

Some of the samples collected, inferred as carbonate nodules, were removed from the CARB sample set, as they contained no carbonate. These anomalous nodules were interpreted as dropstones. On the contrary, some SED samples were added to the CARB sample set because further investigations (XRD, smear slide 
observations, and examination of $50-250 \mu \mathrm{m}$ and $>250 \mu \mathrm{m}$ sieved fractions) indicate that their carbonate fraction was mainly authigenic (not detrital or biogenic).

Samples were dried and ground in an agate mortar for carbonate content measurement using a ManoCalcimeter Mélières (MCM) apparatus derived from the carbonate bomb technique first described by Müller and Gastner (1971).

Total carbonate content (in weight percent) was calculated from $\mathrm{CO}_{2}$ volume evolved from the reaction of $100 \mathrm{mg}$ of finely crushed sediment with $8 \mathrm{~N} \mathrm{HCl}$. The MCM apparatus is calibrated at $100 \%$ so that $1 \mathrm{mM}$ of $\mathrm{CO}_{2}$ corresponds to $100 \mathrm{mg}$ of calcite or aragonite. For other carbonates with different molecular weights, $100 \mathrm{mg}$ does not correspond to $1 \mathrm{mM}$ of $\mathrm{CO}_{2}$, and values must be corrected (e.g., percent dolomite $=\mathrm{MCM} /$ 1.0855 and percent siderite $=\mathrm{MCM} / 0.8639$ ) to estimate the real weight percentages.

Analyses were performed at Muséum National d'Histoire Naturelle (MNHN), Paris (France). The run time was 5-15 min for each sample, depending on carbonate composition (dolomite-rich samples react more slowly).

Because of the low carbonate values observed in the first SED samples analyzed (Site U1328), the quantity of sediment powder used for carbonate determination was increased to $200 \mathrm{mg}$ for Sites U1325-U1327 and U1329 sediments in order to improve measurement accuracy.

To visualize the carbonate content fluctuations measured on the MCM apparatus, uncorrected values were used. These values are equivalent to the $\mathrm{CaCO}_{3}$ weight percent calculated from inorganic carbon determined with the Coulometrics 5011 coulometer on board the JOIDES Resolution, as described by Pimmel and Claypool (2001). Therefore, the shipboard data published in the site chapters and the shore-based MCM data can be used together to compare downhole carbonate fluctuations within and between holes.

All SED and CARB samples were analyzed by XRD to identify the minerals present and to give an estimation of the mineralogical composition of the carbonate fraction. XRD analyses of randomly oriented powders were performed using a Siemens D500 instrument (CuKa Ni filtered radiation) at MNHN. Instrument parameters were set to $40 \mathrm{kV}$ accelerating voltage and $30 \mathrm{~mA}$ current. Scans were run from $2^{\circ} 2 \theta$ to $64^{\circ} 2 \theta$ with a step size of $0.02^{\circ} 2 \theta$ and counting time of $1 \mathrm{~s}$ for standard sediments or $2 \mathrm{~s}$ for authigenic carbonates. If necessary, the position of the peaks was corrected by reference to the main quartz peak present in all samples.

Identification of the main minerals present in the samples was determined with Eva 8.0 software and the International Centre for Diffraction Data (ICCD) Powder Diffraction File 2 database, release 2002.

The Mac Diff 4.2.5 program by Rainer Petschik (servermac.geologie.uni-frankfurt.de/Staff/Homepages/ Petschick/RainerE.html) was used to resolve the composite peaks by a peak-fitting technique and to measure the peak surface of carbonates.

Microfacies (smear slides or thin sections) were examined to determine the morphology and probable origin of the carbonates (detrital, biogenous, or authigenic). For the micritic fine-grained facies, scanning electron microscopy (SEM) images of selected samples (mainly from Sites U1328 and U1327) were used to illustrate crystal morphologies, and energy dispersive spectrometer (EDS) analyses was used to confirm the semiquantitative composition of the carbonates.

Semiquantitative carbonate percentages are given for carbonate-rich samples based on the surface of the main peak of each mineral corrected by arbitrary factors (I/Icor values given in the ICCD database for pure calcite, dolomite, siderite, and rhodochrosite) and on the MCM value for absolute weight percent. The relative error of the weight percent of a given carbonate phase is roughly estimated at $\pm 5 \%$ but may be higher because

- Authigenic calcite and dolomite have highly variable characteristics, as reflected by the wide range of $\mathrm{d}_{104}$ values (Fig. F2);

- Siderite $\left(\mathrm{d}_{104} \approx 2.796 \AA\right)$ and rhodochrosite $\left(\mathrm{d}_{104} \approx\right.$ $2.850 \AA$ ), as determined from XRD, may correspond to other complex carbonate phases (Fe, $\mathrm{Mg}$, $\mathrm{Ca}$, and sometimes $\mathrm{Mn}$ in EDS analyses);

- I/Icor values for nonstoichiometric calcites or dolomites are not known; and

- Feldspars s.l. (Ca-albite, microcline, anorthite, etc.) or amphiboles (hornblende), which are sometimes abundant, have secondary peaks (around 2.99, 2.94, and $2.90 \AA$ ) superposed over the main carbonate peaks.

The $\mathrm{d}_{104}$ values of calcite were used to calculate their content in $\mathrm{mol} \% \mathrm{MgCO}_{3}$ using a linear interpolation between interplanar spacings of stoichiometric dolomite $\left(\mathrm{d}_{104}=2.886\right)$ and stoichiometric calcite $\left(\mathrm{d}_{104}=\right.$ 3.035), as experimentally observed by Goldsmith and Graf (1958). This method was not used to estimate dolomite composition, as the position of the $\mathrm{d}_{104}$ peak depends on the incorporation of $\mathrm{Mg}^{2+}$, 
$\mathrm{Ca}^{2+}, \mathrm{Mn}^{2+}$, and $\mathrm{Fe}^{2+}$, and our microprobe analysis (EDS spectra) show that Fe is sometimes present in the dolomite crystal lattice.

\section{Results}

XRD analyses show that SED samples from Sites U1325-U1329 are dominated by detrital minerals, mainly quartz, plagioclases and potassium feldspars, micas, clay minerals, amphiboles, and sometimes pyroxenes (e.g., diopside). Some pyrite and carbonate minerals are also present as minor components. Magnetic minerals (magnetite and greigite) (Esteban and Enkin, 2007) are also present but were not identified in the raw samples analyzed by XRD, even if they sometimes seemed relatively abundant during clay fraction extraction.

Because of the inhomogeneous nature of the sediment (Expedition 311 Scientists, 2005) the mineralogical composition varies considerably vertically and laterally. We did not attempt to quantify the mineral phases present in the bulk samples because

- Phyllites, amphiboles, and feldspars s.l. have variable compositions;

- Many minerals are present near or below the detection limit; and

- Superposition of peaks is frequent.

In this report we focus only on the carbonate phases, whereas Bartier et al. focus on the clay mineralogy ( $<2 \mu \mathrm{m}$ fraction) of selected samples.

\section{SED samples}

Carbonate (MCM) analyses indicate that SED samples are carbonate poor (mean values $\approx 2-3 \mathrm{wt} \%$ ) (Table T1). Calcite, mainly low-Mg calcite (LMC) with a $\mathrm{d}_{104}$ peak between 3.035 and $3.030 \AA$ (Table T2), is the dominant carbonate phase with some dolomite $\left(\mathrm{d}_{104}\right.$ peak usually located between 2.885 and 2.900 $\AA$ ); other carbonates were generally not detected. In these low-carbonate samples, the relative abundance of detrital minerals makes quantification of calcite and dolomite percentages uncertain, as albite interferes with high-Mg calcite (HMC) and microcline interferes with nonstoichiometric dolomite; therefore, only the total carbonate percentage is given.

Site U1326 is located on top of the first uplifted ridge of accreted sediments at the far western downslope end of the transect (Fig. F1). Sediments from this site show the lowest carbonate contents of the transect (Fig. F3; Table T2). Slightly higher values in lithostratigraphic Unit I may correspond to calcareous microfossil remains, as observed in Sample 311U1326C-3H-5, 80-82 cm (5.5 wt\% carbonate with nearly stoichiometric calcite and abundant foraminifers on sieved fractions). However, carbonate contents in Samples 311-U1326C-4H-3, 75-77 cm (26.65 meters below seafloor [mbsf]), 311-U1326D-2X-4, 75-77 cm (93.65 mbsf), and 15X-1, 73-75 cm (214.33 mbsf), may correspond to some authigenic carbonate cement scattered in the sediment, as suggested by the composition of calcite $(5-7.7 \mathrm{~mol} \%$ $\mathrm{MgCO}_{3}$ ) (Table T2). Sample 311-U1326D-2X-1, 72 $74 \mathrm{~cm}$ (MCM values $\approx 10 \mathrm{wt} \%)$, originally a SED sample, was added to the CARB series because irregular carbonate grains $(\sim 6 \mu \mathrm{m}$ in diameter and $6.5 \mathrm{~mol} \%$ $\mathrm{MgCO}_{3}$ in calcite) and almost no calcareous microfossil remains were observed in sieved fractions and smear slides. In addition, the mousselike texture observed in the section may be associated with dissociation of gas hydrate.

Site U1325 is located within the first slope basin in the southwestern part of the transect cored during Expedition 311 (Fig. F1). In lithostratigraphic Units I and III (see the "Site U1325" chapter), biogenic components (very abundant foraminifers sometimes observed in the sieved fractions) are more abundant, as reflected by the slightly higher amount of carbonate observed in the sediments (Fig. F4; Table T2), although they drop to very low values in lithostratigraphic Units II and IV (almost no foraminifers observed in the sieved fractions). In sediments, calcite is generally nearly stoichiometric, except in Samples 311-U1325B-10X-1, 75-77 cm (73.55 mbsf), 311-U1325C-7X-6, 75-77 cm (233.42 mbsf), and $8 \mathrm{X}-4,75-77 \mathrm{~cm}(241.40 \mathrm{mbsf})$, with $7.7,5.0$, and $4.4 \mathrm{~mol} \% \mathrm{MgCO}_{3}$ in calcite, respectively (Table T2). This is interpreted as corresponding to biogenic components.

Site U1327 is located near the middle of the coring transect on a broad uplifted ridge of accreted sediments about mid-slope up the margin, near Ocean Drilling Program (ODP) Leg 146 Site 889 (375 m southeast from Hole 889C) (Fig. F1). In lithostratigraphic Unit I, interstitial water geochemistry results predict authigenic carbonate formation within the sulfate reduction and alkalinity generation zone (see the "Site U1327" chapter); however, no authigenic carbonate cement was found. Slightly higher carbonate contents were found in samples from 0 to 32.5 mbsf ( $0-2 \mathrm{~mol}^{2} \mathrm{MgCO}_{3}$ in calcite). Carbonate contents of sediments throughout the lithostratigraphic units are generally low, with slightly higher values in Samples 311-U1327C-3H-1, 75-77 cm (16.35 mbsf), $4 \mathrm{H}-3$, 75-77 cm (28.85 mbsf), 9H-6, 75-77 cm (73.35 mbsf), and 13X-4, 75-77 cm (107.75 mbsf), which are associated with foraminifer-rich intervals and substoichiometric calcite. However, as at Site U1326, carbonate contents in Samples 311-U1327C-12X-6, 
$75-77 \mathrm{~cm}$ (99.87 mbsf), 18X-3, 75-77 cm (144.60 mbsf), and 31X-5, 75-77 cm (263.81 mbsf), might correspond to some authigenic carbonate particles scattered in the sediment, as suggested by the composition of calcite $\left(\sim 6 \mathrm{~mol} \% \mathrm{MgCO}_{3}\right)$ (Table T2; Fig. F5). Sample 311-U1327C-19X-1, 75-77 cm (MCM value $\approx 20 \mathrm{wt} \%$ ), was added to the original CARB series, as the carbonate value is not explained by calcareous organisms and corresponds mainly to HMC (11.8 $\mathrm{mol}_{\%} \mathrm{MgCO}_{3}$ ).

Site U1329 is the easternmost and shallowest site of the transect and is interpreted to be located near the eastern limit of gas hydrate occurrence on the northern Cascadia margin (Fig. F1). Moreover, it is the only site with Miocene sediments (lithostratigraphic Unit III) occurring in discordance below Pleistocene sediments. The sediments at Site U1329 have the highest carbonate values (up to $18.6 \mathrm{wt} \%$ in Sample 311-U1329C-3H-2, 75-77 cm) (Table T2; Fig. F4) of the transect and mainly correspond to foraminiferor calcareous nannoplankton-rich levels, as shown by examination of some smear slides and sieved fractions and to substoichiometric calcite. Miocene sediments of lithostratigraphic Unit III contain almost no carbonates $(0-3 \mathrm{wt} \%$; average value $\approx 1 \mathrm{wt} \%)$ compared to the upper part of the series. At Site $\mathrm{U} 1328$, the average value of carbonates is $3.2 \mathrm{wt} \%$ ( 3.7 $\mathrm{wt} \%$ if Miocene sediments are excluded), whereas Sites U1326-U1327 contain lower carbonate contents ( $2 \mathrm{wt} \%)$; along the transect, carbonate contents decrease with distance to the shoreline. As at Sites U1326 and U1327, some authigenic carbonate may be scattered in the sediment (calcite, siderite, and/or dolomite), but their identification is difficult except in Sample 311-U1329C-21X-1, 75-77 cm (170.05 mbsf), the carbonate paragenesis of which (5.4 $\mathrm{mol} \% \mathrm{MgCO}_{3}$ calcite + siderite) is similar to nearby CARB Sample 311-U1329C-21X-2, 118-120 $\mathrm{cm}$ (mainly siderite $+7.4 \mathrm{~mol} \% \mathrm{MgCO}_{3}$ calcite)

Site U1328 is an active cold seep (Bullseye vent site) associated with faults located $3.7 \mathrm{~km}$ southeast of Site U1327, on the mid-continental slope off Vancouver Island (British Columbia) (Fig. F1). It is characterized by a massive accumulation of gas hydrate in the upper $\sim 40 \mathrm{~m}$ of the series. Carbonate contents of the sediments (average $=2.6 \mathrm{wt} \%$ ) (Tables T1, T2; Fig. F7) are slightly higher than at nearby Site U1327 (average $=2.2 \mathrm{wt} \%$ ). This may be due to the presence of dispersed authigenic carbonate crystals throughout the cores. For example, the presence of HMC in the upper part of the cores (0-38 mbsf) is inferred from the intensity of the peak around $3.0 \AA$ (corresponding to $10-11 \mathrm{~mol}^{2} \mathrm{MgCO}_{3}$ in calcite) (Table T2). However, LMC $\left(0-3.5 \mathrm{~mol}^{\circ} \mathrm{MgCO}_{3}\right)$ is the main carbonate present, and most of the carbonaterich sediments correspond to foraminifer-rich levels (Table T2).

\section{CARB samples}

XRD diffractograms of the carbonate-rich samples show that the $d_{104}$ reflection peak for some calcites and dolomites is asymmetrical and formed by the superposition of two peaks. This indicates that those carbonates are heterogeneous, with different populations contributing to the composite diffractogram peaks.

From the distribution of $\mathrm{d}_{104}$ values (Fig. F2; Table T2) we distinguish the following:

- Stoichiometric to low-Mg calcite (3.035-3.025 ̊) corresponding to $0-3.4 \mathrm{~mol} \% \mathrm{MgCO}_{3}$ (associated with foraminifers and nannoplankton remains) or medium-Mg calcite (MMC) (3.025-3.01 $\AA$ ) corresponding to $3.4-8.4 \mathrm{~mol} \% \mathrm{MgCO}_{3}$;

- Very high magnesium calcite (3.010-2.984 Å) corresponding to $8.4-17.1 \mathrm{~mol} \% \mathrm{MgCO}_{3}$;

- Nonstoichiometric dolomite (LMD) with $\mathrm{d}_{104}$ varying between 2.944 and $2.905 \AA$ and variable chemical composition $(\mathrm{Ca}, \mathrm{Mg}$, some $\mathrm{Fe}$, but no $\mathrm{Mn}$ in EDS spectra recorded); and

- More stoichiometric dolomite (HMD) with $\mathrm{d}_{104}$ varying between 2.905 and $2.887 \AA$.

\section{Site U1326}

At Site U1326, salinity and chlorinity data (see the "Site U1326" chapter) indicate that gas hydrate is present in the zone extending from $\sim 45$ to 270 mbsf, predominantly occurring in the sandy layers. Seven carbonate-rich samples were analyzed from Site U1326 (Table T3; Fig. F3); calcite, dolomite, and sometimes rhodochrosite and siderite were identified.

In lithostratigraphic Unit I, carbonates correspond mainly to unlithified carbonate cement, as well as partly lithified carbonate, observed between 0.97 and 2.15 mbsf in intervals 311-U1326B-1H-1, 95-102 $\mathrm{cm}$; $1 \mathrm{H}-1,149-150 \mathrm{~cm}$; and $1 \mathrm{H}-2,62-80 \mathrm{~cm}$ (see the "Site U1326" chapter). The concretion sampled at 6.32 mbsf (Sample 311-U1326C-2H-2, 92-93 cm) is composed of a mixture of LMD $\left(\mathrm{d}_{104}=2.914 \AA\right)$ and magnesian calcite ( $\left.7 \mathrm{~mol} \% \mathrm{MgCO}_{3}\right)$.

In lithostratigraphic Unit II, carbonates correspond mainly to unlithified carbonate cement, observed between 40 and 119 mbsf with some lithified carbonates (e.g., Sample 311-U1326C-9X-2, 92-93 cm). 
Dolomite $\left(\mathrm{d}_{104}=2.900-2.905 \AA\right)$ is the main carbonate present.

In lithostratigraphic Unit III, carbonate contents are lower than above (16-33 wt\%) and correspond to carbonate cements composed of magnesian calcite (8.7 and $7.7 \mathrm{~mol} \% \mathrm{MgCO}_{3}$ in Samples 311-U1326D$9 \mathrm{X}-1,0-1 \mathrm{~cm}$, and $17 \mathrm{X}-3,0-100 \mathrm{~cm}$, respectively) or to a mixture of rhodochrosite $\left(\mathrm{d}_{104} \approx 2.841 \AA\right.$ instead of $2.850 \AA)$, very high magnesium calcite $(13.8 \mathrm{~mol} \%$ $\left.\mathrm{MgCO}_{3}\right)$, siderite $\left(\mathrm{d}_{104} \approx 2.795 \AA\right)$, and dolomite in Sample 311-U1326D-20X-3, 0-1 cm, which is near the base of the gas hydrate stability zone (BGHSZ) (264 mbsf).

\section{Site U1325}

At Site U1325, salinity and chlorinity data (see the "Site U1325" chapter) indicate that gas hydrate is present from $~ 70$ to 240 mbsf, predominantly occupying the sandy layers and some of it also being associated with the clay lithology in the $50 \mathrm{~m}$ above the bottom-simulating reflector (BSR) ( 180-230 mbsf). No carbonate cement or concretion was observed in the upper part of these slope basin sediments (lithostratigraphic Units I and II), only one in Unit III ( 127 mbsf), and two in Unit IV ( 222 and 258 mbsf) (Table T3; Fig. F4). These carbonates contain variable proportions of calcite and dolomite.

In lithostratigraphic Unit III, a layer of cemented carbonate occurs in interval 311-U1325B-16X-6, 27-33 $\mathrm{cm}$. XRD analysis of Sample 311-U1325B-16X-6, 28$30 \mathrm{~cm}$, confirms a combination of LMD $\left(\mathrm{d}_{104}=2.902\right.$ $\AA$ ) and $\mathrm{HMC}\left(10.7 \mathrm{~mol}_{\mathrm{O}} \mathrm{MgCO}_{3}\right)$.

In lithostratigraphic Unit IV, Sample 311-U1325C$6 \mathrm{X}-4,47-48 \mathrm{~cm}$, is mainly composed of a mixture of LMD $\left(\mathrm{d}_{104}=2.924 \AA\right)$ and HMD $\left(\mathrm{d}_{104}=2.895 \AA\right)$, whereas HMC (10.4 mol\% $\left.\mathrm{MgCO}_{3}\right)$ dominates in Sample 311-U1325C-11X-1, 119-122 cm.

\section{Site U1327}

At Site U1327, salinity and chlorinity data (see the "Site U1327" chapter) indicate that gas hydrate is present in the zone extending from $\sim 128$ mbsf to the BSR ( 223 mbsf). Fifteen of the diagenetic carbonate levels sampled were analyzed and showed calcite, dolomite, and sometimes siderite (Table T3; Fig. F4). Most of them occur in the gas hydrate zone (see the "Site U1327" chapter). The first authigenic carbonate occurrence corresponds to a light-colored unlithified cement zone (interval 311-U1327C-10H-1, 95$103 \mathrm{~cm}$ ) (see Fig. F15 in the "Site U1327" chapter) and is mainly composed of $6.7 \mathrm{~mol} \% \mathrm{MgCO}_{3} \mathrm{HMC}$ and some dolomite at $96-98 \mathrm{~cm}$.
In lithostratigraphic Unit II, few unlithified carbonate cements and numerous lithified carbonates are present. Magnesium calcite $\left(6-16 \mathrm{~mol}^{\circ} \mathrm{MgCO}_{3}\right)$ and dolomite (HMD, $\mathrm{d}_{104}=2.893-2.903 \AA$; LMD, $\mathrm{d}_{104}=$ 2.92-2.93 $\AA$ ) are the dominant carbonate phases. Siderite is present either as a major component of the carbonate fraction (72\% in Sample 311-U1327C$16 \mathrm{X}-2,120-150 \mathrm{~cm} ; \mathrm{d}_{104} \approx 2.794 \AA$ ) or as a minor phase (7\% in Sample 311-U1327C-20X-5, 6-7 cm; $\mathrm{d}_{104} \approx 2.786 \AA$ ).

In lithostratigraphic Unit III, few unlithified carbonate cements, visible as faint light spots, occur; XRD shipboard analyses shows a combination of HMC with LMD in most of the cores or a combination of rhodochrosite with HMC and calcium-rich dolomite in Samples 311-U1327C-29X-4, 59-60 cm, and 30X$3,80-81 \mathrm{~cm}$ ( $243 \mathrm{mbsf})$. Lithified carbonate rocks (Table T3) correspond to dolomite $\left(\mathrm{d}_{104}=2.897 \AA\right.$ in Sample 311-U1327C-21X-7, 0-1 cm) or $\sim 5.5 \mathrm{~mol} \%$ $\mathrm{MgCO}_{3}$ calcite (Samples 311-U1327E-16X-CC, 10-11 $\mathrm{cm}$, and $18-19 \mathrm{~cm})$. Previous shipboard analyses of lithified carbonate rocks from interval 311-U1327C24P-1, 0-69 cm, show different carbonate mineralogies (substoichiometric dolomite to LMD and/or HMC).

\section{Site U1329}

Site U1329 is at the eastern limit of gas hydrate occurrence on the northern Cascadia margin. Seismic indicators of gas hydrate are present but more subdued than at all the other sites. Only minor cold anomalies were detected in the cores from this site, consistent with evidence of only minor amounts of gas hydrate based on logging-while-drilling resistivity measurements and chlorinity analyses (see the "Site U1329" chapter). Thirty-three carbonate samples were analyzed from this site (Table T3; Fig. F6) showing calcite, dolomite, and sometimes siderite.

In lithostratigraphic Unit I, authigenic carbonates correspond to unlithified carbonate cements, as well as lithified and partly lithified carbonates. All are mainly composed of HMD $\left(\mathrm{d}_{104}=2.897-2.905 \AA\right)$ with some LMD $\left(\mathrm{d}_{104}=2.922-2.906 \AA\right)$ and sometimes substoichiometric calcite. Previous interstitial water geochemistry results $(\mathrm{Mg}, \mathrm{Ca}$, and $\mathrm{Mg} / \mathrm{Ca}$ values) suggesting dolomitization reactions at $\sim 30 \mathrm{mbsf}$ may explain these dolomite occurrences around 31 mbsf.

In lithostratigraphic Unit II, authigenic carbonates, more or less lithified, are dispersed throughout the series. Calcite (mainly HMC with 13-14 mol\% $\left.\mathrm{MgCO}_{3}\right)$ is the dominant phase except in two sam- 
ples (311-U1329C-5H-6, 61-63 cm, and 311-U1329E$8 \mathrm{Y}-1,35-37 \mathrm{~cm})$, where HMD $\left(\mathrm{d}_{104}=2.905\right.$ and 2.894 $\AA$, respectively) is dominant.

In lithostratigraphic Unit III, unlithified carbonate cements and lithified and partly lithified carbonates are abundant throughout the cores. Pure dolomites (HMD; $\left.\mathrm{d}_{104}=2.894-2.897 \AA\right)$ or calcites $(\sim 12.5 \mathrm{~mol} \%$ $\mathrm{MgCO}_{3}$ [160-165 mbsf], 5.4-6 mol\% $\mathrm{MgCO}_{3}$ [172.91 mbsf], and $2.3 \mathrm{~mol}^{2} \mathrm{MgCO}_{3}$ [187.75 mbsf]) occur, as well as mixtures of calcite and/or dolomite and/or siderite. Sample 311-U1329C-22X-CC, 72-74 cm (187.75 mbsf), with pure LMC (2.3 $\left.\mathrm{mol} \% \mathrm{MgCO}_{3}\right)$ exhibits a microsparitic facies quite different from the clotted micrite facies usually observed in the other sampled carbonate facies and may be related to the conglomerate deposit found just below in pressure Core 311-U1329C-23P and interpreted as a major event, possibly a debris flow (see the "Site U1329" chapter). HMD ( $\mathrm{d}_{104}=2.894-2.905 \AA$ ), HMC (10.4-13.4 mol\% $\mathrm{MgCO}_{3}$ ), and $\mathrm{MMC}$ (5.4-8.1 mol\% $\left.\mathrm{MgCO}_{3}\right)$ are the dominant carbonate phases present in lithostratigraphic Unit III, whereas siderite (4\%$93 \%$ of the carbonate fraction; $d_{104} \approx 2.805-2.809 \AA$ ) is less abundant.

\section{Site U1328}

Site U1328 (Bullseye vent site) is located within an area of active cold vents, where previous dives conducted in 2000 and 2001 with the remotely operated vehicle ROPOS found $10-15 \mathrm{~cm}$ thick carbonate sheets covering an area of $>10 \mathrm{~m}^{2}$ of the seafloor. Gas hydrate distribution at Site U1328 is bimodal, as gas hydrates occur mainly close to the seafloor (0-35 mbsf) and just above the BSR (215-222 mbsf) (see the "Site U1328" chapter). Thirty-one authigenic carbonate samples were analyzed from this site (Table T3; Fig. F7) with calcite and/or dolomite and/or aragonite. The authigenic carbonates were found in lithostratigraphic Units I (1-37 mbsf) and III (220$277 \mathrm{mbsf})$ and Sample 311-U1328C-5P-1, 0-2 cm (92 mbsf?), probably originating from Unit I (fallen block?).

In lithostratigraphic Unit I, to $36.46 \mathrm{mbsf}$, HMC (8.7-17.1 $\mathrm{mol} \% \mathrm{MgCO}_{3}$ ) is the dominant carbonate phase. The HMC is sometimes pure (Sample 311U1328E-2X-1, 52-54 cm) but is most often mixed with dolomite $\left(\mathrm{d}_{104}=2.894-2.939 \AA\right)$ and/or aragonite.

In lithostratigraphic Unit III HMC (12.4-16.1 mol\% $\mathrm{MgCO}_{3}$ ) is the dominant carbonate phase near the BGHSZ, whereas near-stoichiometric dolomite $\left(\mathrm{d}_{104}=\right.$ 2.887-2.895 Å) appears between 253 and 276 mbsf.
Site U1328 differs from the other sites because of the presence of aragonite $(8 \%-46 \%$ of the carbonate fraction) between 6 and 16 mbsf. This site is also characterized by less abundant dolomite and the absence of siderite and rhodochrosite.

\section{Main occurrences of authigenic carbonate minerals based on XRD analyses of CARB samples}

Aragonite is only present in the upper $16 \mathrm{mbsf}$ of the active vent site (U1328), and is associated with calcite and dolomite (Fig. F8A, F8B). The occurrence of aragonite fits well with the predicted gas hydrate content (highest in the upper 15 mbsf; see the "Site U1328" chapter). In the samples studied, aragonite is associated with abundant HMC (13.1-16.8 mol\% $\left.\mathrm{MgCO}_{3}\right)$ and with some LMD $\left(\mathrm{d}_{104}=2.911-2.939 \AA\right)$. The link between aragonite and gas hydrate or methane venting was often observed in recently studied sediments (e.g., Hydrate Ridge on the Cascadia continental margin) (Teichert et al., 2005; Teichert and Bohrmann, 2006).

Calcite is most abundant at the active vent Site U1328 (average content $=\sim 68 \%$ in the carbonate fraction and $47 \%-53 \%$ in the transect sites), where it corresponds mainly to $\mathrm{HMC}$ (8.7-17.1 $\mathrm{mol} \%$ $\mathrm{MgCO}_{3}$ ) (Fig. F8B-F8D). Calcite at transect sites shows more variable compositions with MMC (5.4$8.1 \mathrm{~mol} \% \mathrm{MgCO}_{3}$ ) and/or HMC (8.7-14.1 $\mathrm{mol} \%$ $\left.\mathrm{MgCO}_{3}\right) . \mathrm{LMC}$ is rare and is mainly associated with calcareous biological or detrital remains, based on thin section or smear slide examinations.

Dolomite is well represented in all trasect sites, whereas it is less abundant at Site U1328 (mean average value in carbonate fraction is $\sim 28 \%$, instead of $40 \%-53 \%)$. Dolomite shows variable compositions $\left(\mathrm{d}_{104}=2.987-2.944 \AA\right)$, sometimes with two phases associated in the same sample. LMD, mainly represented at Site U1328, often shows rounded dolomite grains with a knobbly surface (Fig. F8E), whereas HMD often shows euhedral crystals.

From our data, siderite (Fig. F9A-F9C) is mainly observed at Sites U1329 (associated with calcite) and U1327 (associated with calcite and dolomite). This phase was identified from XRD diagrams $\left(\mathrm{d}_{104} \approx\right.$ 2.795-2.809 $\AA$ instead of $2.796 \AA$ ), but EDS analyses of the more carbonate rich part of Sample 311U1329C-21X-3, $129-131 \mathrm{~cm}\left(\mathrm{~d}_{104} \approx 2.809 \AA\right)$, reflect a high content of $\mathrm{Mg}, \mathrm{Fe}$, and $\mathrm{Ca}$ corresponding to an intermediate phase between magnesite, siderite, and calcite. Complementary analyses such as transmission electron microscopy coupled with microanaly- 
ses of individual particles are needed to better characterize what we are recognizing as siderite.

Rhodochrosite is briefly observed from our data at Sites U1326 and U1327 near or below the BGHSZ. This phase was identified from XRD diagrams $\left(\mathrm{d}_{104} \approx\right.$ $2.850 \AA)$. As it is only a minor component $(<15$ wt\%), SEM observation of this phase is difficult. A very fine grained facies was observed in Sample 311U1326D-20X-3, $0-1 \mathrm{~cm}\left(\mathrm{~d}_{104} \approx 2.841 \AA\right.$ instead of $2.850 \AA$ ), showing areas $<1 \mu \mathrm{m}$ in size composed of bladelike particles or euhedral nanocrystals (Fig. F9D, F9E, F9G, F9H). From EDS analyses (Fig. F9F) rhodochrosite may not exist, as these carbonate-rich areas are enriched in $\mathrm{Ca}, \mathrm{Mg}$, and Fe but show little $\mathrm{Mn}$. As for the presence of siderite, further studies are needed.

\section{Acknowledgments}

The authors would like to thank Anne-Marie Brunet, Pierre Clément (MNHN, Paris, France) for help with carbonatometry and XRD analyses and Omar Boudouma (UPMC, Paris, France) for the SEM observations and EDS analyses. The authors thank Joel E. Johnson and editor Lorri Peters for their careful review of the manuscript. This research used samples and/or data provided by the Integrated Ocean Drilling Program (IODP). Funding for this research was provided by an Eclipse II grant of the CNRS.

\section{References}

Bohrmann, G., Greinert, J., Suess, E., and Torres, M., 1998. Authigenic carbonates from the Cascadia subduction zone and their relation to gas hydrate stability. Geology, 26(7):647-650. doi:10.1130/0091-

7613(1998)026<0647:ACFTCS >2.3.CO;2

Esteban, L., and Enkin, R.J., 2007. Relation between magnetism and gas hydrates at the northern Cascadia margin, IODP Expedition 311 [presented at the IODP Expedition 311 2nd Postexpedition Meeting, 23-25 April 2007, Paris, France]. (Abstract)
Expedition 311 Scientists, 2005. Cascadia margin gas hydrates. IODP Prel. Rept., 311. doi:10.2204/ iodp.pr.311.2005

Goldsmith, J.R., and Graf, D.L., 1958. Relations between lattice constraints and composition of the Ca-Mg carbonates. Am. Mineral., 43:84-101.

Greinert, J., Bohrmann, G., and Suess, E., 2001. Gas hydrate-associated carbonates and methane-venting at Hydrate Ridge: classification, distribution and origin of authigenic lithologies. In Paul, C.K., and Dillon, W.P. (Eds.), Natural Gas Hydrates: Occurrence, Distribution, and Detection. Geophys. Monogr., 124:99-114.

Müller, G., and Gastner, M., 1971. The "Karbonat-Bombe," a simple device for the determination of the carbonate content in sediments, soils and other materials. Neues Jahrb. Mineral. Monatsh., 10:466-469.

Pimmel, A., and Claypool, G., 2001. Introduction to shipboard organic geochemistry on the JOIDES Resolution. ODP Tech. Note, 30. doi:10.2973/odp.tn.30.2001

Sample, J.C., and Kopf, A., 1995. Isotope geochemistry of syntectonic carbonate cements and veins from the Oregon margin: implications for the hydrogeologic evolution of the accretionary wedge. In Carson, B., Westbrook, G.K., Musgrave, R.J., and Suess, E. (Eds.), Proc. ODP, Sci. Results, 146 (Pt. 1): College Station, TX (Ocean Drilling Program), 137-148. doi:10.2973/ odp.proc.sr.146-1.235.1995

Teichert, B.M.A., Gussone, N., Eisenhauer, A., and Bohrmann, G., 2005. Clathrites: archives of nearseafloor pore-fluid evolution $\left(\delta^{44 / 40} \mathrm{Ca}, \delta^{13} \mathrm{C}, \delta^{18} \mathrm{O}\right)$ in gas hydrate environments. Geology, 3(3)3:213-216. doi:10.1130/G21317.1

Teichert, B.M.A., and Bohrmann, G., 2006. Data report: composition of authigenic carbonates in sediments of the Cascadia accretionary prism, ODP Leg 204. In Tréhu, A.M., Bohrmann, G., Torres, M.E., and Colwell, F.S. (Eds.), Proc. ODP, Sci. Results, 204: College Station, TX (Ocean Drilling Program), 1-8. doi:10.2973/ odp.proc.sr.204.116.2006

Initial receipt: 06 June 2008

Acceptance: 22 September 2008

Publication: 23 March 2009

MS 311-204 
Figure F1. A. Plate tectonic setting of the Cascadia margin with general location of the drilling transect near previous Ocean Drilling Program (ODP) Sites 889/890. Gray shaded area = bottom-simulating reflector $(\sim 50 \%$ of the mid-continental slope). B. Multibeam bathymetry map along the transect across the accretionary prism with locations of transect Sites U1326-U1327 and U1329, cold vent Site U1328, and multichannel seismic (MCS) Line 89-08.

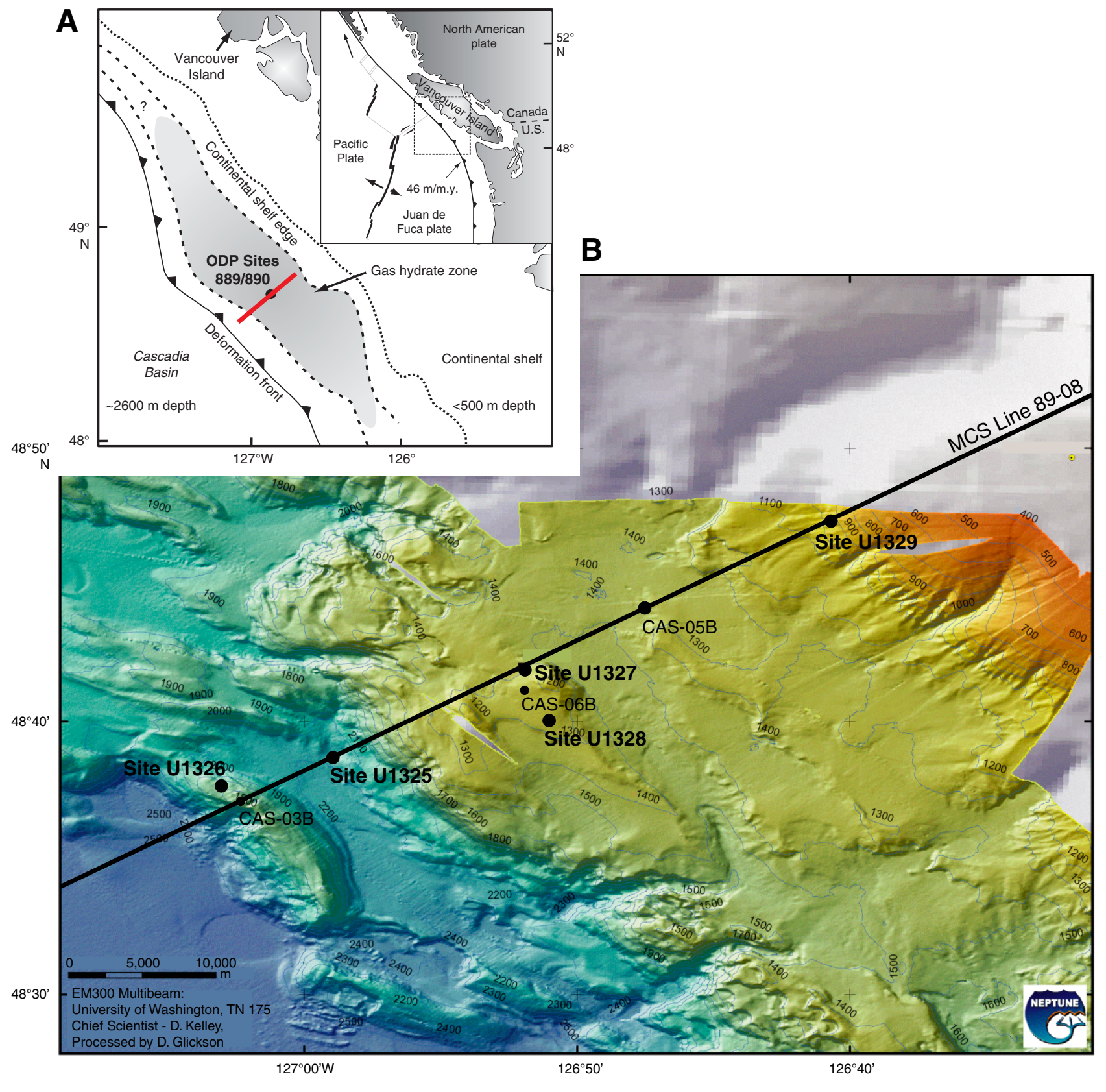


Figure F2. Frequency of observed $d_{104}$ values for authigenic calcite and dolomite samples, Expedition 311 . LMMC = stoichiometric calcite and low- to medium-magnesium calcite $\left(\mathrm{d}_{104}=3.035-3.010 \AA\right), \mathrm{HMC}=$ highmagnesium calcite $\left(\mathrm{d}_{104}=3.010-2.894 \AA\right), \mathrm{LMD}=$ low-magnesium dolomite $\left(\mathrm{d}_{104}=2.944-2.905 \AA\right), \mathrm{HMD}=$ high-magnesium dolomite to stoichiometric dolomite $\left(\mathrm{d}_{104}=2.905-2.887 \AA\right.$ ).

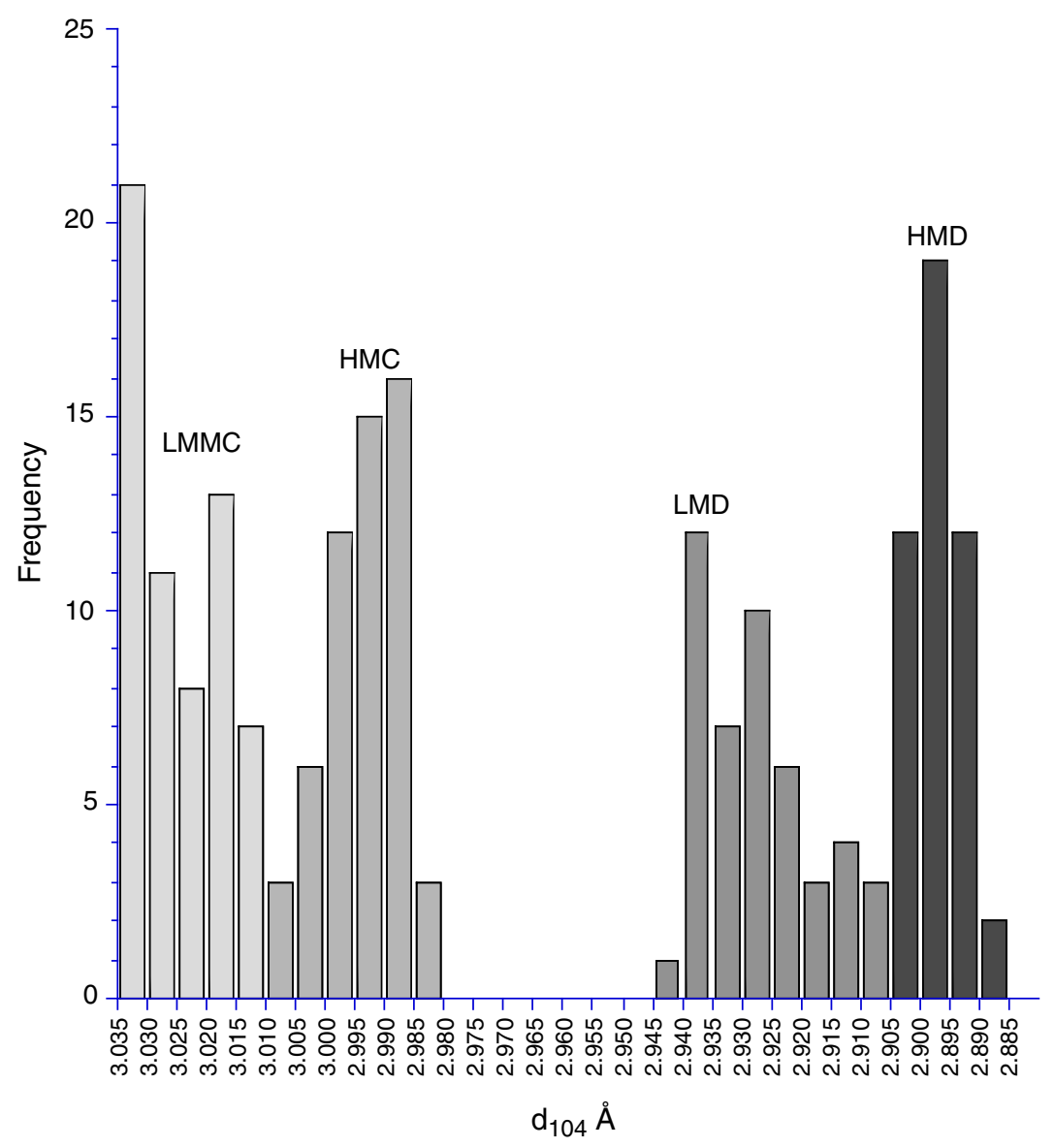


Figure F3. Downhole variations of carbonates in sediment and authigenic carbonate samples, Site U1326. Lith. $=$ lithologic, $\mathrm{SED}=$ standard sediment, $\mathrm{CARB}=$ semi-indurated to indurated authigenic carbonate sediment, BGHSZ = bottom gas hydrate stability zone. The carbonate weight percent shipboard value of Sample 311U1326C-1H-2, 65-80 cm (2.15 mbsf), was plotted with authigenic carbonate samples because unlithified to partly lithified carbonates were observed onboard between 0.97 and 2.15 mbsf.

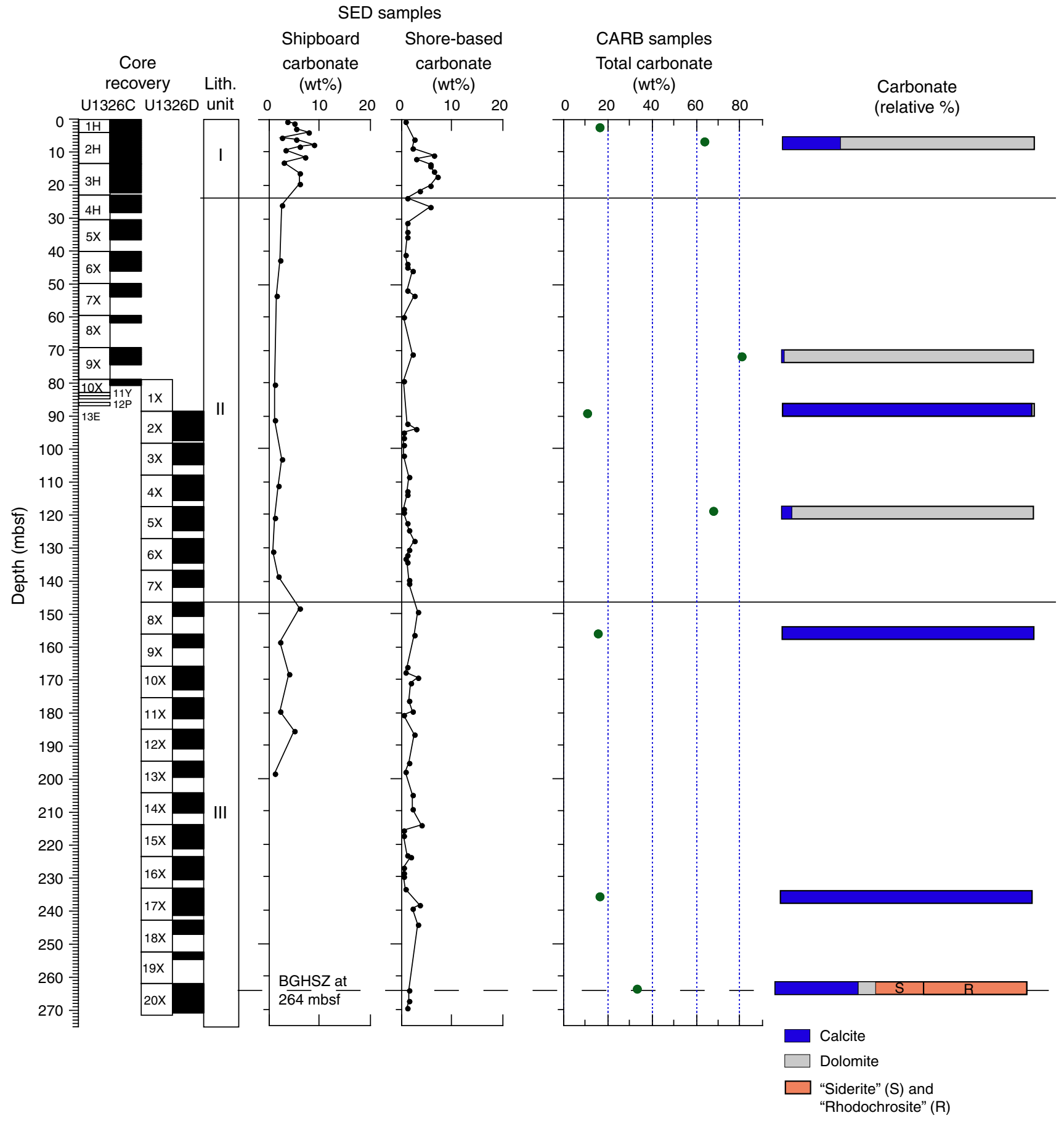


Figure F4. Downhole variations of carbonates in sediment and authigenic carbonate samples, Site U1325. Lith. $=$ lithologic, $\mathrm{SED}=$ standard sediment, $\mathrm{CARB}=$ semi-indurated to indurated authigenic carbonate sediment, BGHSZ = bottom gas hydrate stability zone.

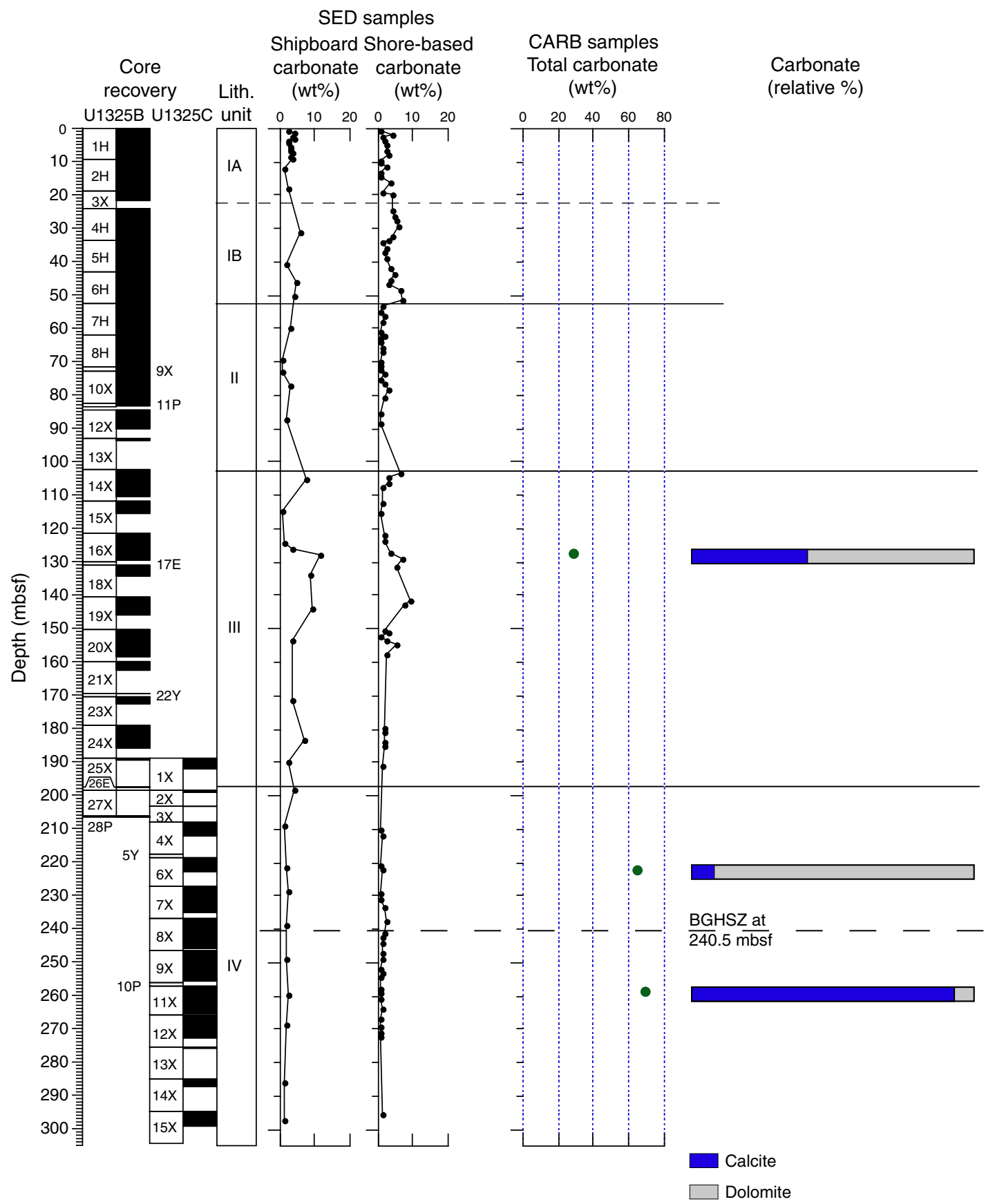


Figure F5. Downhole variations of carbonates in sediment and authigenic carbonate samples, Site U1327. Lith. $=$ lithologic, $\mathrm{SED}=$ standard sediment, $\mathrm{CARB}=$ semi-indurated to indurated authigenic carbonate sediment, BGHSZ = bottom gas hydrate stability zone. XRD shipboard data were added for Cores 311-U1327C-24P, 29X, and $30 \mathrm{X}$.

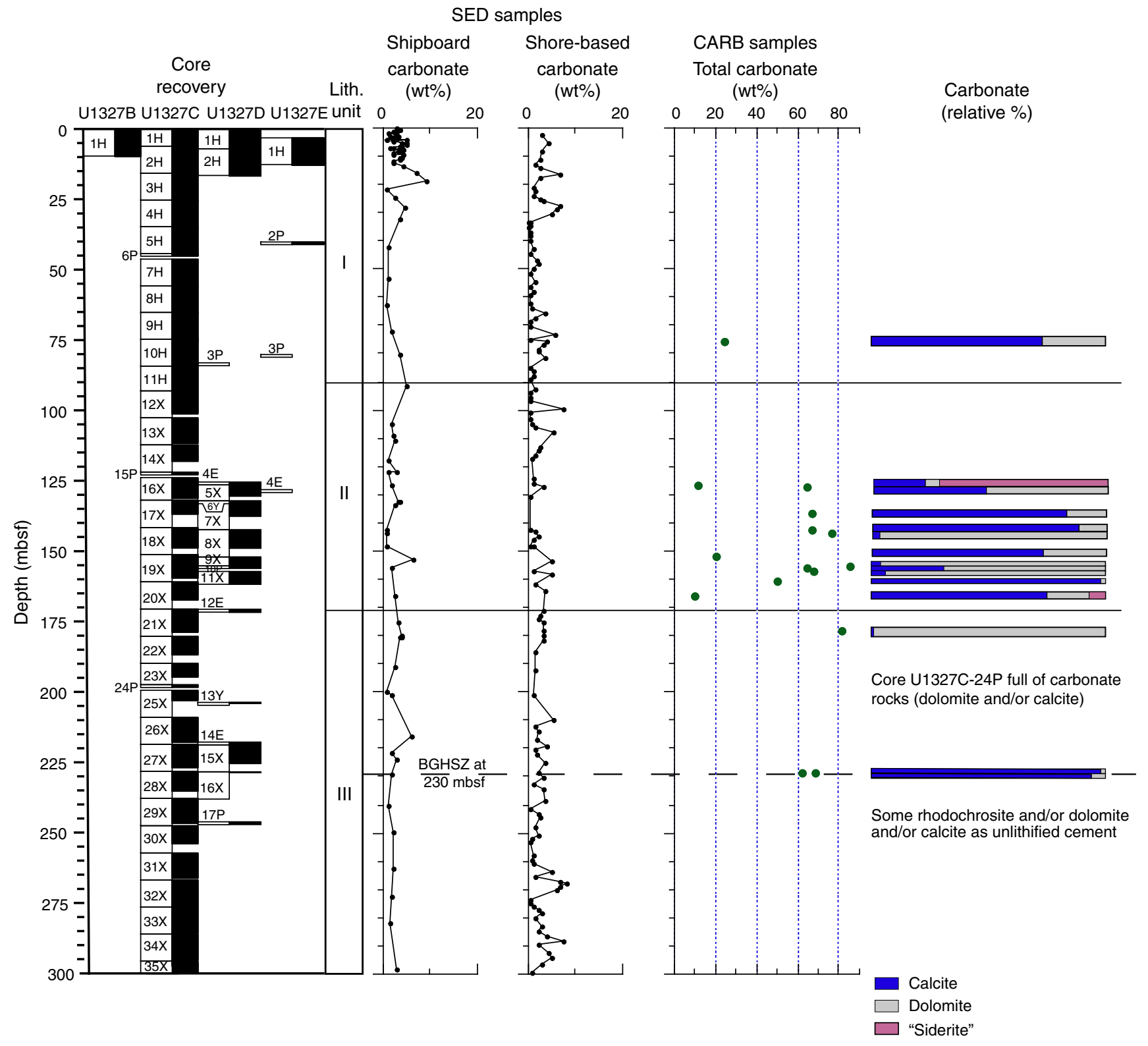


Figure F6. Downhole variations of carbonates in sediment and authigenic carbonate samples, Site U1329. Lith. $=$ lithologic, $\mathrm{SED}=$ standard sediment, $\mathrm{CARB}=$ semi-indurated to indurated authigenic carbonate sediment, BGHSZ = bottom gas hydrate stability zone.

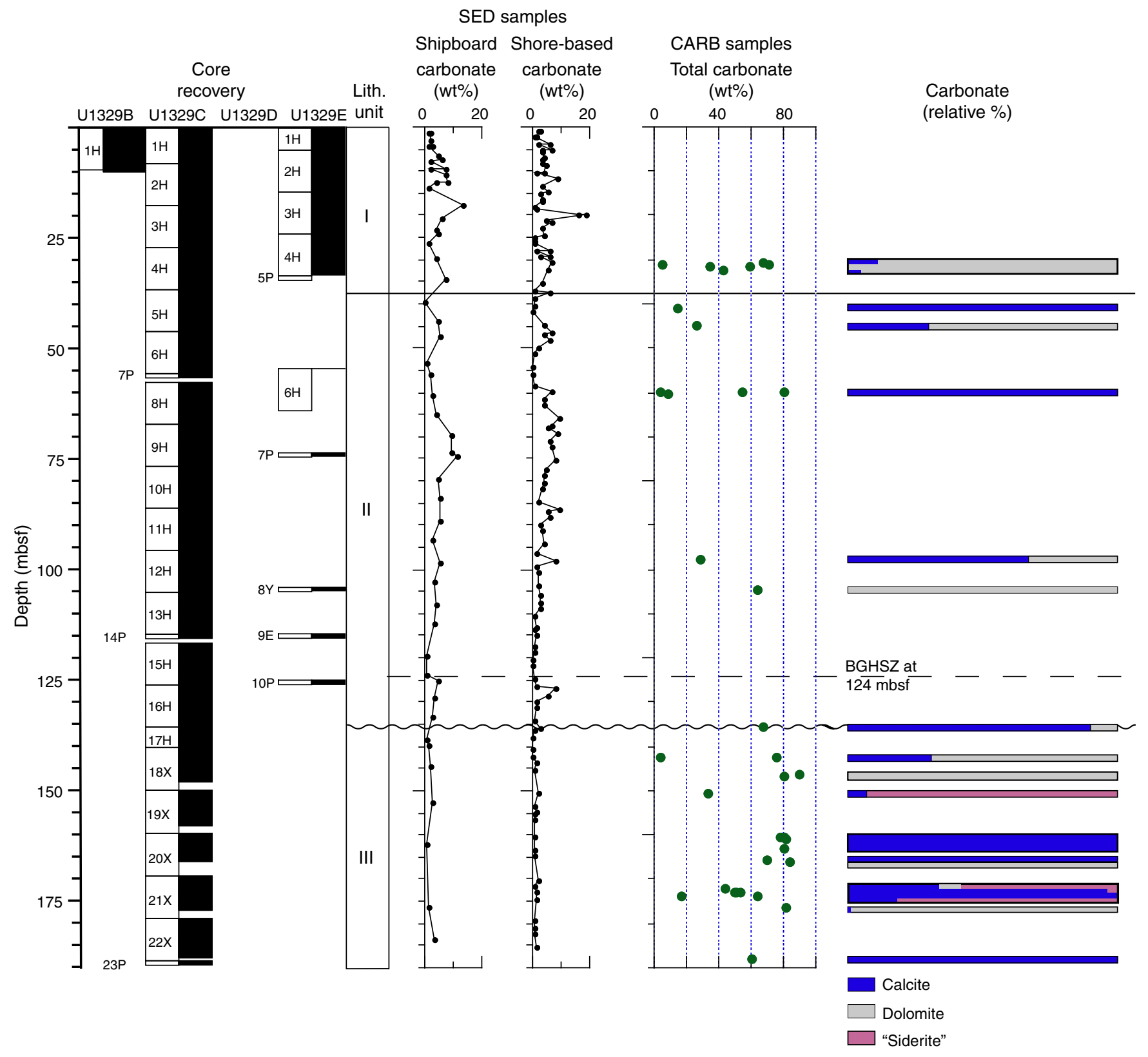


Figure F7. Downhole variations of carbonates in sediment and authigenic carbonate samples, Site U1328. ManoCalcimeter Mélières values and carbonate relative percent not plotted for Sample 311-U1328C-5P-1, 0-2 $\mathrm{cm}$, and Hole U1328D samples with uncertain depths. Lith. = lithologic, SED = standard sediment, CARB = semi-indurated to indurated authigenic carbonate sediment, BGHSZ = bottom gas hydrate stability zone

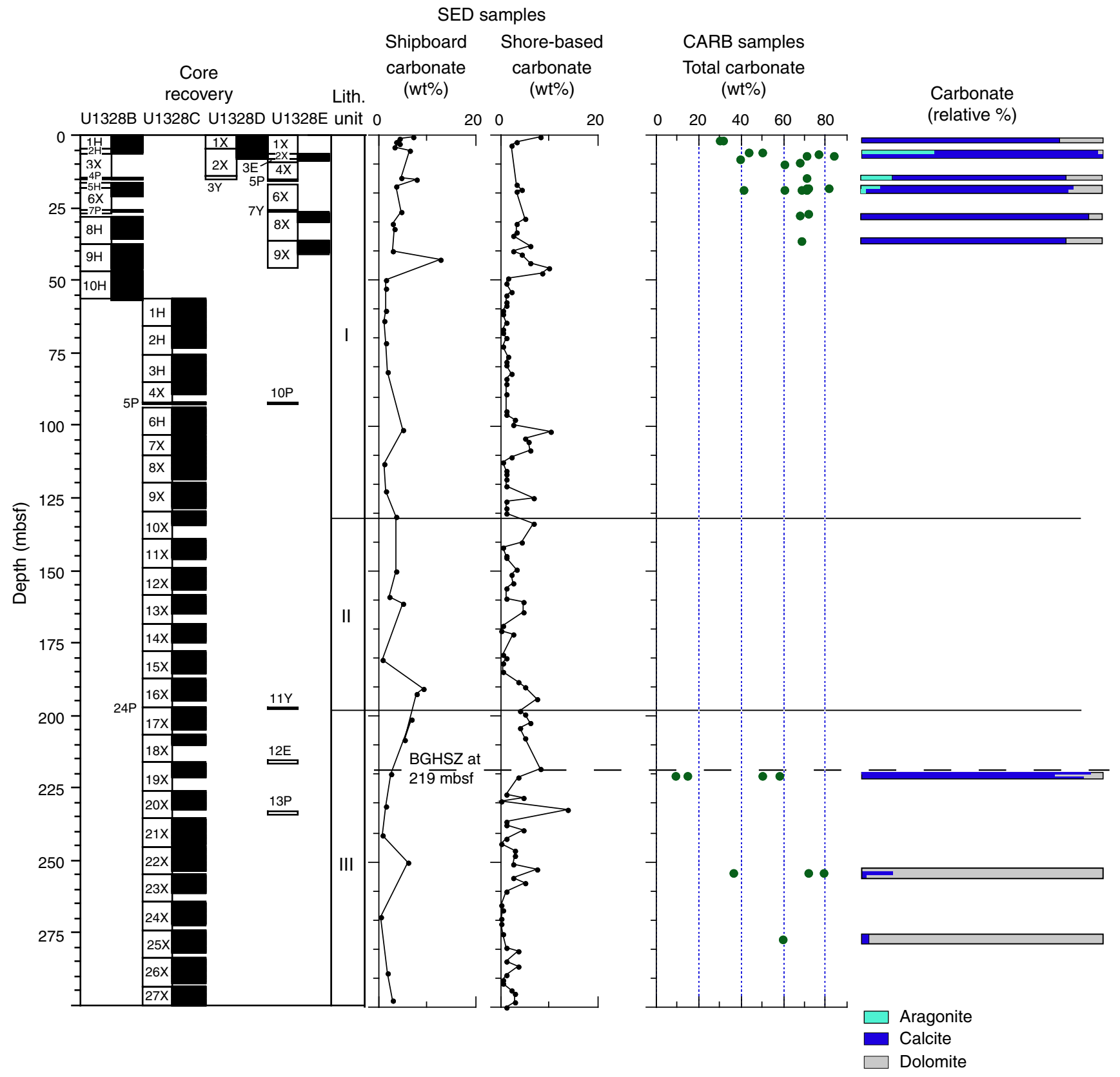


Figure F8. Scanning electron microscopy photographs of Site U1328 cold seep carbonate facies. A. General view (backscattered electron) showing the association of aragonite needles and small high-magnesium calcite $(\mathrm{HMC})$ crystals $\left(\sim 13 \mathrm{~mol} \% \mathrm{MgCO}_{3}\right)$ with knobbly surface (Sample 311-U1328B-6X-1, 0-20 cm). B. Secondary electron detail of A. C. Energy dispersive spectrometer (EDS) spectrum of HMC crystal (arrow in B). D. Small HMC crystals $\left(\sim 16 \mathrm{~mol}^{2} \mathrm{MgCO}_{3}\right)$ with knobbly surface (Sample 311-U1328B-6X-1, 47-50 cm). E. Clusters of rounded dolomite grains with knobbly surface (Sample 311-U1328D-2X-2, 30-31 cm). F. EDS spectrum for sample in E.
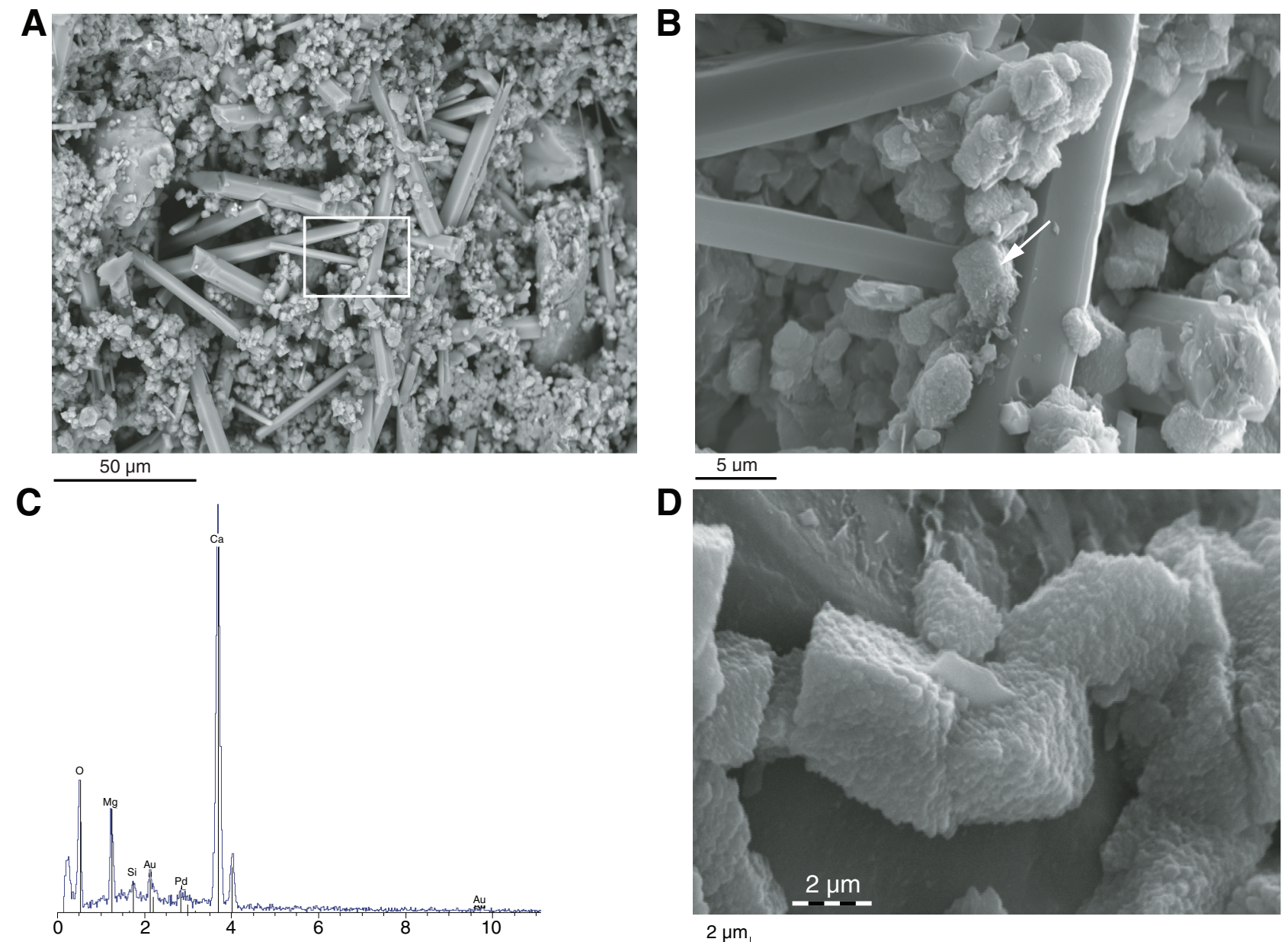

D

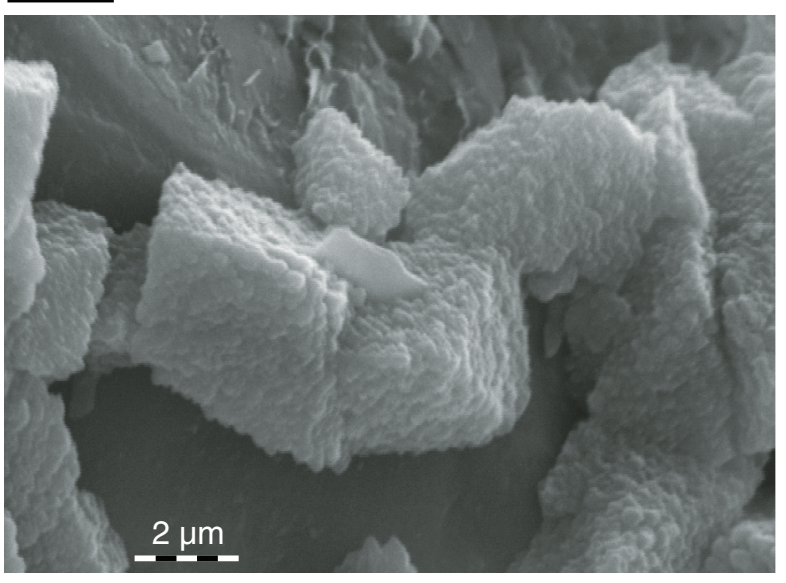

$\mathbf{E}$
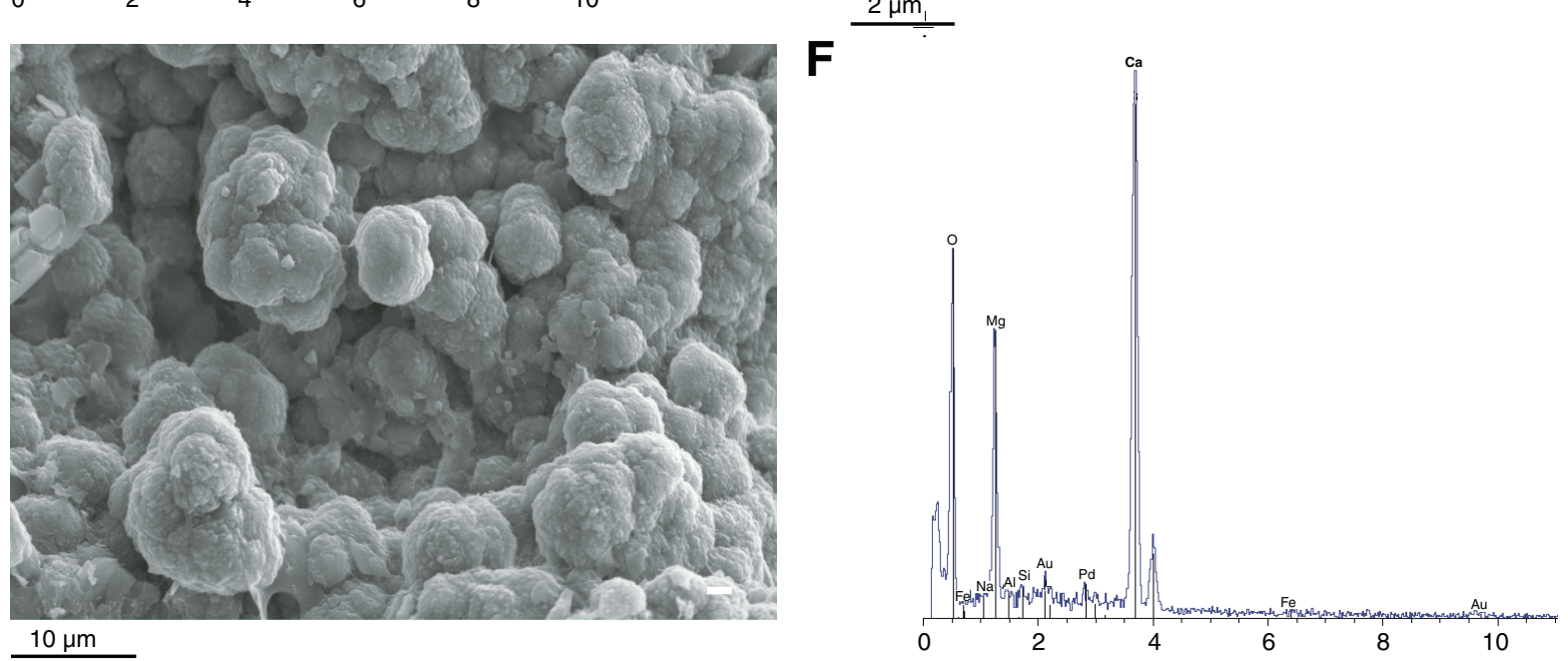
Figure F9. Scanning electron microscopy photographs of siderite and rhodochrosite authigenic facies. A. General view (backscattered electron [BSE]) of rhombohedra (1-4 $\mu \mathrm{m})($ Sample 311-U1329C-21X-3, 129-131 cm). B. Secondary electron (SE) detail view of A. C. Energy dispersive spectrometer (EDS) spectrum corresponding to an intermediate phase between magnesite, siderite, and calcite (see $\mathrm{Mg}$, Fe, and Ca in EDS spectra). Corresponding XRD diagram appears indicate siderite with all peaks translated toward higher values (e.g., $\mathrm{d}_{104} \approx$ $2.809 \AA$ instead of $2.796 \AA$ ). D. SE photograph showing carbonates corresponding to thin areas ( $<1 \mu \mathrm{m}$; arrows) scattered in the detrital matrix (Sample 311-U1326D-20X-3, 0-1 cm). E. Dispersed fragments of sample in D observed on a glass slide (BSE). F. EDS spectrum of sample in E with $\mathrm{Ca}, \mathrm{Fe}, \mathrm{Mg}$, and some $\mathrm{Mn}$ in the carbonates. G. Higher magnification of E showing aligned bladelike particles. H. Higher magnification of E showing rhombic crystals.
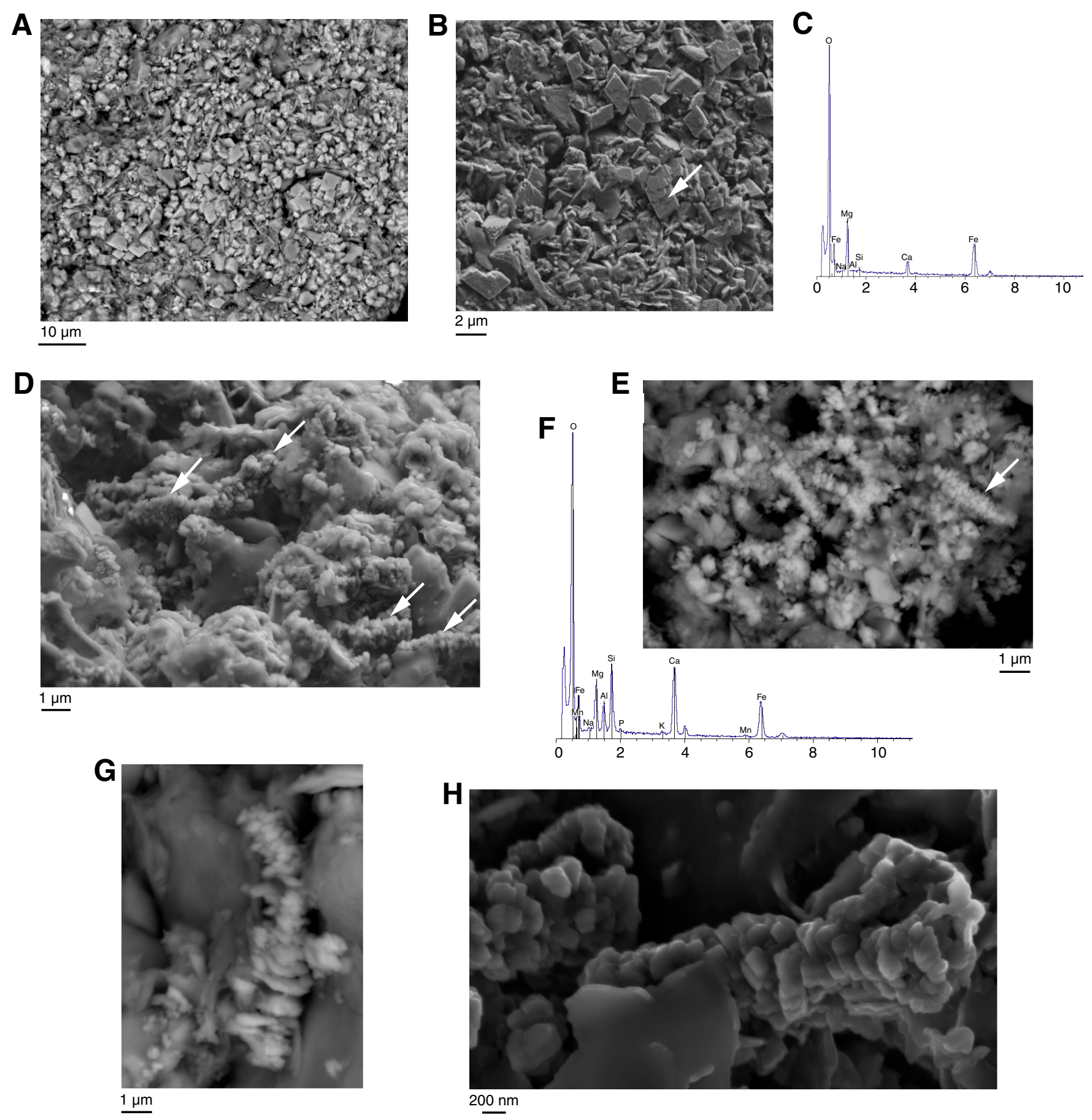
Table T1. Sediment carbonate content. (See table note.)

\begin{tabular}{|c|c|c|c|c|c|}
\hline \multirow[b]{2}{*}{ Site } & \multirow{2}{*}{$\begin{array}{l}\text { Depth } \\
\text { (mbsf) }\end{array}$} & \multicolumn{2}{|c|}{$\begin{array}{c}\text { MCM values } \\
(w t \%)\end{array}$} & \multicolumn{2}{|c|}{$\begin{array}{l}\mathrm{MCM}+\text { shipboard } \\
\text { values (wt } \%)\end{array}$} \\
\hline & & Range & Average & Range & Average \\
\hline U1326 & 1828 & $0.3-7$ & 1.9 & $0.3-8.7$ & 2.4 \\
\hline U1325 & 2195 & $0.5-9.3$ & 2.1 & $0.5-11.4$ & 2.4 \\
\hline U1327 & 1304 & $0-8.1$ & 2.2 & $0-9.2$ & 2.5 \\
\hline U1329 & 946 & $0.3-18.6$ & 3.2 & $0.3-18.6$ & 3.4 \\
\hline U1328 & 1268 & $0.3-13.6$ & 2.6 & $0.3-13.6$ & 2.9 \\
\hline
\end{tabular}

Note: $\mathrm{MCM}=$ ManoCalcimeter Mélières apparatus. 
Table T2. Total carbonate content and mineralogical calcite composition. (See table notes.) (Continued on the next eight pages.)

\begin{tabular}{|c|c|c|c|c|c|}
\hline $\begin{array}{l}\text { Core, section, } \\
\text { interval }(\mathrm{cm})\end{array}$ & $\begin{array}{l}\text { Depth } \\
\text { (mbsf) }\end{array}$ & $\begin{array}{l}\text { MCM } \\
(w t \%)\end{array}$ & $\begin{array}{l}\text { Calcite } \\
\left(\mathrm{d}_{104} \AA\right)\end{array}$ & $\begin{array}{l}\mathrm{MgCO}_{3} \\
(\mathrm{~mol} \%)\end{array}$ & Remarks \\
\hline \multicolumn{6}{|l|}{ 311-U1325B- } \\
\hline $1 \mathrm{H}-2,43-45$ & 1.93 & 3.8 & 3.034 & 0.3 & \\
\hline $1 \mathrm{H}-4,48-50$ & 4.98 & 2.5 & 3.032 & 1.0 & \\
\hline $1 \mathrm{H}-5,49-51$ & 6.49 & 2.5 & 3.029 & 2.0 & \\
\hline $1 \mathrm{H}-6,44-46$ & 7.94 & 3.0 & 3.032 & 1.0 & \\
\hline $1 \mathrm{H}-7,31-33$ & 9.31 & 0.8 & 3.028 & 2.3 & \\
\hline $2 \mathrm{H}-1,75-77$ & 10.05 & 0.5 & - & & \\
\hline $2 \mathrm{H}-2,75-77$ & 11.55 & 2.5 & 3.029 & 2.0 & \\
\hline $2 \mathrm{H}-3,75-77$ & 13.05 & 0.5 & ND & ND & \\
\hline $2 \mathrm{H}-4,75-77$ & 14.55 & 0.8 & ND & ND & \\
\hline $2 \mathrm{H}-5,75-77$ & 16.05 & 3.5 & 3.032 & 1.0 & \\
\hline $2 \mathrm{H}-7,75-77$ & 19.05 & 1.3 & 3.030 & 1.7 & \\
\hline $3 X-1,75-77$ & 19.55 & 3.8 & 3.033 & 0.7 & \\
\hline $4 \mathrm{H}-1,75-77$ & 24.75 & 4.3 & 3.034 & 0.3 & \\
\hline $4 \mathrm{H}-2,75-77$ & 26.07 & 4.8 & 3.035 & 0.0 & \\
\hline $4 \mathrm{H}-3,75-77$ & 27.57 & 5.3 & 3.034 & 0.3 & \\
\hline $4 \mathrm{H}-4,75-77$ & 29.07 & 5.6 & 3.035 & 0.0 & \\
\hline $4 \mathrm{H}-6,75-77$ & 32.07 & 4.0 & 3.035 & 0.0 & \\
\hline $4 \mathrm{H}-7,62-64$ & 33.44 & 3.0 & 3.035 & 0.0 & \\
\hline $5 \mathrm{H}-1,75-77$ & 34.25 & 1.0 & 3.035 & 0.0 & \\
\hline $5 \mathrm{H}-2,75-77$ & 35.75 & 2.3 & 3.034 & 0.3 & \\
\hline $5 \mathrm{H}-3,75-77$ & 37.17 & 1.8 & 3.033 & 0.7 & \\
\hline $5 \mathrm{H}-4,75-77$ & 38.67 & 2.5 & 3.034 & 0.3 & \\
\hline $5 \mathrm{H}-6,75-77$ & 41.67 & 3.3 & 3.031 & 1.3 & \\
\hline $6 \mathrm{H}-1,75-77$ & 43.75 & 4.5 & 3.035 & 0.0 & \\
\hline $6 \mathrm{H}-2,75-77$ & 45.25 & 3.8 & 3.034 & 0.3 & \\
\hline $6 \mathrm{H}-3,75-77$ & 46.75 & 2.8 & 3.035 & 0.0 & \\
\hline $6 \mathrm{H}-4,75-77$ & 48.25 & 6.3 & 3.034 & 0.3 & \\
\hline $6 \mathrm{H}-6,78-80$ & 51.28 & 6.8 & 3.034 & 0.3 & \\
\hline $7 \mathrm{H}-1,58-60$ & 53.08 & 1.0 & 3.035 & 0.0 & \\
\hline $7 \mathrm{H}-2,75-77$ & 54.75 & 0.5 & ND & ND & \\
\hline $7 \mathrm{H}-3,75-77$ & 56.25 & 1.5 & 3.026 & 3.0 & \\
\hline $7 \mathrm{H}-4,78-80$ & 57.78 & 1.0 & 3.034 & 0.3 & \\
\hline $7 \mathrm{H}-6,75-77$ & 60.75 & 0.5 & ND & ND & \\
\hline $7 \mathrm{H}-7,71-73$ & 61.97 & 1.5 & 3.030 & 1.7 & \\
\hline $8 \mathrm{H}-1,75-77$ & 62.75 & 0.5 & ND & ND & \\
\hline $8 \mathrm{H}-2,75-77$ & 64.01 & 0.8 & ND & ND & \\
\hline $8 \mathrm{H}-3,75-77$ & 65.51 & 1.0 & 3.031 & 1.3 & \\
\hline $8 \mathrm{H}-4,75-77$ & 67.01 & 1.0 & 3.032 & 1.0 & \\
\hline $8 \mathrm{H}-6,75-77$ & 70.01 & 0.5 & - & & \\
\hline $8 \mathrm{H}-7,75-77$ & 71.01 & 0.5 & ND & ND & \\
\hline $9 X-1,75-77$ & 72.25 & 0.5 & - & & \\
\hline $10 X-1,75-77$ & 73.55 & 1.5 & 3.012 & 7.7 & \\
\hline $10 X-2,75-77$ & 75.05 & 0.8 & ND & ND & \\
\hline $10 X-3,75-77$ & 76.55 & 2.0 & 3.028 & 2.3 & \\
\hline $10 X-4,75-77$ & 78.05 & 2.8 & 3.030 & 1.7 & \\
\hline $10 X-6,75-77$ & 80.85 & 1.5 & 3.032 & 1.0 & \\
\hline $12 X-1,75-77$ & 85.15 & 0.5 & - & & \\
\hline $12 X-3,75-77$ & 88.15 & 0.8 & ND & ND & \\
\hline $14 X-1,75-77$ & 103.05 & 6.3 & 3.034 & 0.3 & \\
\hline $14 X-2,75-77$ & 104.55 & 3.0 & 3.035 & 0.0 & \\
\hline $14 X-3,75-77$ & 106.05 & 3.0 & 3.034 & 0.3 & \\
\hline $14 X-4,75-77$ & 107.55 & 1.3 & 3.034 & 0.3 & \\
\hline $15 X-1,75-77$ & 112.45 & 1.0 & 3.028 & 2.3 & \\
\hline $15 X-3,64-66$ & 115.34 & 0.5 & ND & ND & \\
\hline $16 X-1,75-77$ & 122.05 & 2.0 & 3.034 & 0.3 & \\
\hline $16 X-2,75-77$ & 123.55 & 2.0 & 3.035 & 0.0 & \\
\hline $16 X-6,75-77$ & 127.40 & 3.5 & 3.035 & 0.0 & \\
\hline $16 X-7,75-77$ & 128.90 & 7.0 & 3.035 & 0.0 & \\
\hline $18 X-1,75-77$ & 131.65 & 5.3 & 3.035 & 0.0 & \\
\hline 19X-1, 75-77 & 141.25 & 9.3 & 3.033 & 0.7 & Abundant foraminifers and calcareous nannoplankton \\
\hline $19 X-2,75-77$ & 142.75 & 7.5 & 3.034 & 0.3 & \\
\hline $20 X-1,5-7$ & 150.25 & 2.0 & 3.034 & 0.3 & \\
\hline $20 X-1,75-77$ & 150.95 & 3.0 & 3.03 & 1.7 & \\
\hline $20 X-2,75-77$ & 152.45 & 0.5 & 3.032 & 1.0 & \\
\hline $20 X-3,7-9$ & 153.27 & 2.5 & 3.035 & 0.0 & \\
\hline $20 \times-4,75-77$ & 154.59 & 5.0 & 3.033 & 0.7 & \\
\hline
\end{tabular}


Table T2 (continued). (Continued on next page.)

\begin{tabular}{|c|c|c|c|c|c|}
\hline $\begin{array}{l}\text { Core, section, } \\
\text { interval }(\mathrm{cm})\end{array}$ & $\begin{array}{l}\text { Depth } \\
\text { (mbsf) }\end{array}$ & $\begin{array}{l}\text { MCM } \\
(w t \%)\end{array}$ & $\begin{array}{l}\text { Calcite } \\
\left(\mathrm{d}_{104} \AA\right)\end{array}$ & $\begin{array}{l}\mathrm{MgCO}_{3} \\
(\mathrm{~mol} \%)\end{array}$ & Remarks \\
\hline $20 X-6,77-79$ & 157.61 & 2.3 & 3.034 & 0.3 & \\
\hline $24 X-1,75-77$ & 179.75 & 2.0 & 3.033 & 0.7 & \\
\hline $24 \mathrm{X}-2,75-77$ & 181.14 & 1.8 & 3.032 & 1.0 & \\
\hline $24 X-4,75-77$ & 184.02 & 2.0 & 3.034 & 0.3 & \\
\hline $24 X-5,75-77$ & 185.02 & 1.5 & 3.035 & 0.0 & \\
\hline \multicolumn{6}{|l|}{ 311-U1325C- } \\
\hline $1 X-2,75-77$ & 191.05 & 1.0 & ND & ND & \\
\hline $4 X-2,75-77$ & 209.99 & 0.5 & ND & ND & \\
\hline $4 X-4,75-77$ & 211.67 & 1.0 & 3.027 & 2.7 & \\
\hline $6 X-3,75-77$ & 221.14 & 0.5 & ND & ND & \\
\hline $6 X-4,75-77$ & 222.26 & 1.0 & 3.035 & 0.0 & \\
\hline $7 X-2,75-77$ & 229.45 & 0.5 & ND & ND & \\
\hline $7 X-3,77-79$ & 230.97 & 0.5 & 3.029 & 2.0 & \\
\hline $7 X-6,75-77$ & 233.42 & 1.8 & 3.020 & 5.0 & \\
\hline $8 X-1,75-77$ & 237.55 & 2.3 & 3.031 & 1.3 & \\
\hline $8 X-4,75-77$ & 241.40 & 1.8 & 3.022 & 4.4 & \\
\hline $8 X-5,75-77$ & 242.55 & 1.0 & 3.031 & 1.3 & \\
\hline $8 X-6,75-77$ & 244.05 & 1.3 & 3.028 & 2.3 & \\
\hline $9 X-1,75-77$ & 247.25 & 1.0 & ND & ND & \\
\hline $9 X-2,75-77$ & 248.75 & 1.0 & ND & ND & \\
\hline $9 \times-4,75-77$ & 251.75 & 0.8 & ND & ND & \\
\hline $9 X-5,75-77$ & 253.03 & 1.0 & ND & ND & \\
\hline $9 X-6,71-73$ & 254.49 & 0.8 & - & & \\
\hline $11 X-1,75-77$ & 257.85 & 0.5 & ND & ND & \\
\hline $11 X-2,75-77$ & 259.35 & 0.5 & - & & \\
\hline $11 X-3,73-75$ & 260.83 & 0.5 & - & & \\
\hline $11 X-5,75-77$ & 263.85 & 1.3 & 3.031 & 1.3 & \\
\hline $12 X-1,75-77$ & 266.55 & 0.5 & ND & ND & \\
\hline $12 X-3,75-77$ & 269.42 & 0.8 & ND & ND & \\
\hline $12 X-4,75-77$ & 270.92 & 0.8 & ND & ND & \\
\hline $12 X-5,75-77$ & 272.42 & 0.5 & - & & \\
\hline $15 X-1,75-77$ & 295.45 & 1.0 & ND & ND & \\
\hline \multicolumn{6}{|l|}{ 311-U1325D- } \\
\hline $1 \mathrm{H}-1,76-78$ & 0.76 & 0.5 & 3.032 & 1.0 & \\
\hline $1 \mathrm{H}-2,75-77$ & 2.25 & 1.0 & 3.035 & 0.0 & \\
\hline $1 \mathrm{H}-3,76-78$ & 3.76 & 2.0 & 3.028 & 2.3 & \\
\hline \multicolumn{6}{|l|}{ 311-U1326B- } \\
\hline $1 \mathrm{H}-1,75-77$ & 0.75 & 0.8 & ND & ND & \\
\hline \multicolumn{6}{|l|}{ 311-U1326C- } \\
\hline $2 \mathrm{H}-2,51-53$ & 5.91 & 2.5 & 3.035 & 0.0 & \\
\hline $2 \mathrm{H}-4,51-53$ & 8.91 & 2.0 & 3.034 & 0.3 & \\
\hline $2 \mathrm{H}-5,75-77$ & 10.65 & 6.3 & 3.034 & 0.3 & \\
\hline $2 \mathrm{H}-6,72-74$ & 12.12 & 3.0 & 3.029 & 2.0 & \\
\hline $2 \mathrm{H}-7,47-49$ & 13.37 & 5.8 & 3.029 & 2.0 & \\
\hline $3 \mathrm{H}-1,75-77$ & 14.15 & 5.5 & 3.034 & 0.3 & \\
\hline $3 \mathrm{H}-2,75-77$ & 15.65 & 6.5 & 3.032 & 1.0 & \\
\hline $3 \mathrm{H}-3,75-77$ & 17.15 & 7.0 & 3.030 & 1.7 & Small foraminifers in sieved fraction; coccoliths and detrital carbonates in smearslide \\
\hline $3 \mathrm{H}-5,80-82$ & 20.2 & 5.5 & 3.034 & 0.3 & \\
\hline $3 \mathrm{H}-6,75-77$ & 21.65 & 3.5 & 3.029 & 2.0 & \\
\hline $4 \mathrm{H}-1,75-77$ & 23.65 & 1.0 & 3.031 & 1.3 & \\
\hline $4 \mathrm{H}-3,75-77$ & 26.65 & 5.5 & 3.012 & 7.7 & \\
\hline $5 X-1,75-77$ & 31.15 & 1.3 & 3.03 & 1.7 & \\
\hline $5 X-3,75-77$ & 34.07 & 1.3 & 3.026 & 3.0 & \\
\hline $5 X-4,75-77$ & 35.40 & 1.3 & 3.032 & 1.0 & \\
\hline $6 X-1,75-77$ & 40.75 & 0.8 & 3.028 & 2.3 & \\
\hline $6 \mathrm{X}-3,75-77$ & 43.75 & 1.0 & 3.025 & 3.4 & \\
\hline $6 \times-4,75-77$ & 44.77 & 1.3 & 3.035 & 0.0 & \\
\hline $6 X-5,75-77$ & 45.73 & 2.0 & ND & ND & \\
\hline $7 X-2,75-77$ & 51.78 & 1.3 & 3.034 & 0.3 & \\
\hline $7 X-3,71-73$ & 53.24 & 2.5 & 3.032 & 1.0 & \\
\hline $8 X-1,75-77$ & 60.15 & 0.5 & ND & ND & \\
\hline $9 \times-2,75-77$ & 71.35 & 2.0 & $3.021 ?$ & $4.7 ?$ & \\
\hline $10 X-1,75-77$ & 79.45 & 0.3 & - & & \\
\hline \multicolumn{6}{|l|}{ 311-U1326D- } \\
\hline $2 X-3,75-77$ & 92.15 & 1.0 & $3.022 ?$ & 4.4 & \\
\hline $2 X-4,75-77$ & 93.65 & 2.8 & $3.020 ?$ & $5.0 ?$ & \\
\hline $2 X-5,75-77$ & 95.15 & 0.5 & ND & ND & \\
\hline
\end{tabular}


Table T2 (continued). (Continued on next page.)

\begin{tabular}{|c|c|c|c|c|c|}
\hline $\begin{array}{l}\text { Core, section, } \\
\text { interval }(\mathrm{cm})\end{array}$ & $\begin{array}{l}\text { Depth } \\
\text { (mbsf) }\end{array}$ & $\begin{array}{l}\text { MCM } \\
\text { (wt\%) }\end{array}$ & $\begin{array}{l}\text { Calcite } \\
\left(\mathrm{d}_{104} \AA\right)\end{array}$ & $\begin{array}{l}\mathrm{MgCO}_{3} \\
(\mathrm{~mol} \%)\end{array}$ & Remarks \\
\hline $2 X-6,75-77$ & 96.59 & 0.5 & ND & ND & \\
\hline $3 X-1,75-77$ & 98.85 & 0.5 & - & & \\
\hline $3 X-3,75-77$ & 101.85 & 0.5 & ND & ND & \\
\hline $4 X-1,75-77$ & 108.45 & 1.3 & ND & ND & \\
\hline $4 X-4,75-77$ & 112.51 & 1.0 & 3.026 & 3.0 & \\
\hline $4 X-5,75-77$ & 113.86 & 1.0 & 3.034 & 0.3 & \\
\hline $5 X-1,75-77$ & 118.05 & 0.3 & - & & \\
\hline $5 X-2,75-77$ & 119.45 & 0.5 & - & & \\
\hline $5 X-4,75-77$ & 122.29 & 1.0 & 3.034 & 0.3 & \\
\hline $5 X-6,75-77$ & 124.35 & 1.3 & 3.030 & 1.7 & \\
\hline $6 X-1,75-77$ & 127.75 & 2.3 & 3.034 & 0.3 & \\
\hline $6 X-3,75-77$ & 130.75 & 1.5 & 3.028 & 2.3 & \\
\hline $6 X-4,75-77$ & 131.88 & 1.0 & 3.028 & 2.3 & \\
\hline $6 X-5,75-77$ & 133.20 & 0.8 & ND & ND & \\
\hline $6 X-6,75-77$ & 134.20 & 1.0 & - & & \\
\hline $7 X-3,75-77$ & 139.49 & 1.3 & 3.034 & 0.3 & \\
\hline $7 X-4,75-77$ & 140.94 & 1.5 & 3.030 & 1.7 & \\
\hline $8 X-3,75-77$ & 149.51 & 3.1 & 3.035 & 0.0 & \\
\hline $9 X-1,75-77$ & 156.65 & 2.6 & 3.029 & 2.0 & \\
\hline $10 X-1,75-77$ & 166.35 & 1.0 & ND & ND & \\
\hline $10 X-2,75-77$ & 167.85 & 0.8 & ND & ND & \\
\hline $10 X-3,75-77$ & 169.27 & 3.1 & 3.033 & 0.7 & \\
\hline $10 X-4,75-77$ & 170.77 & 1.8 & 3.031 & 1.3 & \\
\hline $11 X-2,75-77$ & 176.44 & 1.3 & 3.024 & 3.7 & \\
\hline $11 X-4,75-77$ & 179.44 & 2.0 & 3.034 & 0.3 & \\
\hline $11 X-5,75-77$ & 180.94 & 0.5 & ND & ND & \\
\hline $12 X-2,75-77$ & 186.80 & 2.6 & 3.031 & 1.3 & \\
\hline $13 X-1,75-77$ & 195.15 & 1.5 & 3.033 & 0.7 & \\
\hline $13 X-3,75-77$ & 197.75 & 0.8 & ND & ND & \\
\hline $14 X-1,75-77$ & 204.75 & 2.0 & 3.032 & 1.0 & \\
\hline $14 X-5,75-77$ & 209.25 & 2.0 & 3.032 & 1.0 & \\
\hline $15 X-1,73-75$ & 214.33 & 3.8 & 3.013 & 7.4 & \\
\hline $15 X-2,75-77$ & 215.77 & 0.5 & ND & ND & \\
\hline $15 X-3,75-77$ & 217.11 & 0.5 & ND & ND & \\
\hline $16 \mathrm{X}-1,24-26$ & 223.54 & 1.0 & 3.035 & 0.0 & \\
\hline $16 X-1,75-77$ & 224.05 & 1.8 & 3.034 & 0.3 & \\
\hline $16 X-3,75-77$ & 227.05 & 0.3 & - & & \\
\hline $16 X-4,75-77$ & 228.55 & 0.5 & - & & \\
\hline $16 \mathrm{X}-5,75-77$ & 229.65 & 0.5 & - & & \\
\hline $17 X-1,75-77$ & 233.65 & 0.8 & - & & \\
\hline $17 X-4,75-77$ & 238.15 & 3.6 & 3.033 & 0.7 & \\
\hline $17 X-5,75-77$ & 239.65 & 2.0 & 3.032 & 1.0 & \\
\hline $18 X-2,75-77$ & 244.40 & 3.1 & 3.034 & 0.3 & \\
\hline $20 X-3,75-77$ & 264.50 & 1.5 & 3.030 & 1.7 & \\
\hline $20 x-5,75-77$ & 267.29 & 1.3 & 3.032 & 1.0 & \\
\hline $20 x-7,74-76$ & 269.78 & 1.0 & 3.030 & 1.7 & \\
\hline \multicolumn{6}{|l|}{ 311-U1327C- } \\
\hline $1 \mathrm{H}-2,75-77$ & 2.25 & 2.8 & $3.033,3.017$ & $0.7,6.0$ & \\
\hline $1 \mathrm{H}-4,75-77$ & 5.25 & 4.3 & 3.032 & 1.0 & \\
\hline $2 \mathrm{H}-2,75-77$ & 8.35 & 2.8 & 3.035 & 0.0 & \\
\hline $2 \mathrm{H}-4,75-77$ & 11.35 & 2.5 & 3.029 & 2.0 & \\
\hline $2 \mathrm{H}-5,75-77$ & 12.85 & 1.5 & 3.030 & 1.7 & \\
\hline $2 \mathrm{H}-6,72-74$ & 14.32 & 2.5 & 3.031 & 1.3 & \\
\hline $3 \mathrm{H}-1,75-77$ & 16.35 & 6.6 & 3.035 & 0.0 & \\
\hline $3 \mathrm{H}-2,75-77$ & 17.85 & 2.5 & 3.035 & 0.0 & \\
\hline $3 \mathrm{H}-4,81-83$ & 20.91 & 1.3 & 3.030 & 1.7 & \\
\hline $3 \mathrm{H}-5,75-77$ & 22.35 & 1.5 & 3.035 & 0.0 & \\
\hline $3 \mathrm{H}-6,75-77$ & 23.85 & 1.3 & 3.033 & 0.7 & \\
\hline $3 \mathrm{H}-7,75-77$ & 25.35 & 2.5 & 3.032 & 1.0 & \\
\hline $4 \mathrm{H}-1,75-77$ & 25.85 & 3.1 & 3.028 & 2.2 & \\
\hline $4 \mathrm{H}-2,75-77$ & 27.35 & 6.6 & 3.035 & 0.0 & \\
\hline $4 \mathrm{H}-3,75-77$ & 28.85 & 6.1 & 3.033 & 0.7 & \\
\hline $4 \mathrm{H}-4,75-77$ & 30.35 & 4.8 & 3.033 & 0.7 & \\
\hline $4 \mathrm{H}-6,75-77$ & 33.35 & 0.5 & 3.027 & 2.7 & \\
\hline $4 \mathrm{H}-6,83-85$ & 33.43 & 0.0 & - & & Dropstone \\
\hline $4 \mathrm{H}-7,75-77$ & 34.85 & 0.3 & 3.028 & 2.3 & \\
\hline $5 \mathrm{H}-1,75-77$ & 35.35 & 0.0 & - & & \\
\hline $5 \mathrm{H}-2,75-77$ & 36.85 & 0.5 & - & & \\
\hline
\end{tabular}


Table T2 (continued). (Continued on next page.)

\begin{tabular}{|c|c|c|c|c|c|}
\hline $\begin{array}{l}\text { Core, section, } \\
\text { interval }(\mathrm{cm})\end{array}$ & $\begin{array}{l}\text { Depth } \\
\text { (mbsf) }\end{array}$ & $\begin{array}{l}\text { MCM } \\
\text { (wt\%) }\end{array}$ & $\begin{array}{l}\text { Calcite } \\
\left(\mathrm{d}_{104} \AA\right)\end{array}$ & $\begin{array}{l}\mathrm{MgCO}_{3} \\
(\mathrm{~mol} \%)\end{array}$ & Remarks \\
\hline $5 \mathrm{H}-3,75-77$ & 38.35 & 0.5 & ND & ND & \\
\hline $5 \mathrm{H}-4,75-77$ & 39.85 & 0.5 & - & & \\
\hline $5 \mathrm{H}-6,75-77$ & 42.85 & 1.0 & 3.026 & 3.0 & \\
\hline $5 \mathrm{H}-7,75-77$ & 44.35 & 0.3 & - & & \\
\hline 7H-1, 75-77 & 46.85 & 1.8 & 3.033 & 0.7 & \\
\hline 7H-2, 75-77 & 48.35 & 2.0 & 3.035 & 0.0 & \\
\hline 7H-3, 75-77 & 49.85 & 1.3 & 3.030 & 1.7 & \\
\hline 7H-4, 75-77 & 51.35 & 0.5 & ND & ND & \\
\hline 7H-6, 75-77 & 54.35 & 1.5 & 3.030 & 1.7 & \\
\hline $8 \mathrm{H}-1,75-77$ & 56.35 & 0.5 & ND & ND & \\
\hline $8 \mathrm{H}-2,75-77$ & 57.85 & 1.0 & 3.028 & 2.3 & \\
\hline $8 \mathrm{H}-3,75-77$ & 59.35 & 0.5 & ND & ND & \\
\hline $8 \mathrm{H}-5,75-77$ & 62.35 & 0.5 & - & & \\
\hline $8 \mathrm{H}-6,75-77$ & 63.85 & 0.8 & ND & ND & \\
\hline $9 \mathrm{H}-1,75-77$ & 65.85 & 3.5 & 3.033 & 0.7 & \\
\hline $9 \mathrm{H}-2,75-77$ & 67.35 & 1.5 & 3.032 & 1.0 & \\
\hline $9 \mathrm{H}-3,77-79$ & 68.87 & 0.5 & - & & \\
\hline $9 \mathrm{H}-4,75-77$ & 70.35 & 0.3 & - & & \\
\hline $9 \mathrm{H}-6,75-77$ & 73.35 & 5.8 & 3.034 & 0.3 & \\
\hline $9 \mathrm{H}-7,75-77$ & 74.85 & 0.5 & - & & \\
\hline $10 \mathrm{H}-1,75-77$ & 75.35 & 3.8 & 3.035 & 0.0 & \\
\hline $10 \mathrm{H}-2,75-77$ & 76.85 & 3.3 & 3.034 & 0.3 & \\
\hline $10 \mathrm{H}-3,75-77$ & 78.35 & 2.0 & 3.034 & 0.3 & \\
\hline $10 \mathrm{H}-4,0-15$ & 79.10 & 2.1 & 3.032 & 1.0 & \\
\hline $10 \mathrm{H}-6,75-77$ & 81.50 & 3.5 & 3.033 & 0.7 & \\
\hline $11 \mathrm{H}-1,75-77$ & 84.85 & 0.5 & ND & ND & \\
\hline $11 \mathrm{H}-2,75-77$ & 86.35 & 1.0 & ND & ND & \\
\hline $11 \mathrm{H}-3,75-77$ & 87.85 & 1.0 & ND & ND & \\
\hline $11 \mathrm{H}-4,75-77$ & 89.35 & 0.5 & - & & \\
\hline $11 \mathrm{H}-6,75-77$ & 92.35 & 1.5 & 3.036 & & \\
\hline $12 \mathrm{X}-2,75-77$ & 94.01 & 0.5 & - & & \\
\hline $12 X-3,75-77$ & 95.51 & 0.5 & - & & \\
\hline $12 X-4,75-77$ & 97.01 & 0.5 & - & & \\
\hline $12 X-6,75-77$ & 99.87 & 7.5 & $3.028, \mathrm{ND}$ & $2.3, ?$ & \\
\hline $12 X-7,65-67$ & 100.77 & 0.5 & - & & \\
\hline $13 X-1,75-77$ & 103.25 & 0.5 & - & & \\
\hline $13 X-2,75-77$ & 104.75 & 0.8 & - & & \\
\hline $13 X-3,75-77$ & 106.25 & 1.5 & 3.033 & 0.7 & \\
\hline $13 X-4,75-77$ & 107.75 & 5.3 & 3.033 & 0.7 & \\
\hline $14 \mathrm{X}-1,75-77$ & 112.85 & 2.5 & 3.034 & 0.3 & \\
\hline $14 X-2,75-77$ & 114.35 & 2.0 & 3.033 & 0.7 & \\
\hline $14 X-3,75-77$ & 115.85 & 1.5 & 3.034 & 0.3 & \\
\hline $14 X-4,75-77$ & 117.35 & 0.8 & ND & ND & \\
\hline $16 \mathrm{X}-1,75-77$ & 124.55 & 1.3 & 3.028 & 2.3 & \\
\hline $16 \mathrm{X}-2,75-77$ & 125.95 & 1.0 & ND & ND & \\
\hline $16 \mathrm{X}-3,75-77$ & 127.45 & 3.1 & 3.027 & 2.7 & \\
\hline $16 X-5,75-77$ & 130.45 & 0.5 & ND & ND & \\
\hline $18 \mathrm{X}-1,72-74$ & 142.22 & 0.5 & ND & ND & \\
\hline $18 X-2,75-77$ & 143.10 & 1.5 & ND & ND & \\
\hline $18 X-3,75-77$ & 144.60 & 2.0 & 3.017 & 6.0 & \\
\hline $18 X-4,75-77$ & 146.10 & 1.3 & ND & ND & \\
\hline $18 X-5,120-150$ & 148.05 & 0.5 & ND & ND & \\
\hline $19 X-3,75-77$ & 153.85 & 5.1 & 3.035 & 0.0 & \\
\hline $19 X-5,79-81$ & 156.89 & 1.0 & ND & ND & \\
\hline $19 X-6,75-77$ & 158.35 & 4.8 & 3.030 & 1.7 & \\
\hline $20 X-1,75-77$ & 161.55 & 1.5 & 3.034 & 0.3 & \\
\hline $20 X-3,75-77$ & 163.83 & 3.6 & 3.035 & 0.0 & \\
\hline $21 X-1,75-77$ & 171.15 & 3.1 & 3.029 & 2.0 & \\
\hline $21 X-2,72-74$ & 172.62 & 2.6 & 3.029 & 2.0 & \\
\hline $21 X-3,78-80$ & 174.11 & 2.0 & 3.026 & 3.0 & \\
\hline $21 X-4,76-78$ & 175.28 & 3.1 & 3.034 & 0.3 & \\
\hline $21 X-6,75-77$ & 178.17 & 3.1 & 3.033 & 0.7 & \\
\hline $22 X-1,74-76$ & 180.00 & 3.1 & 3.034 & 0.3 & \\
\hline $22 X-2,74-76$ & 181.50 & 3.1 & 3.033 & 0.7 & \\
\hline $22 X-5,75-77$ & 186.00 & 1.5 & 3.031 & 1.3 & \\
\hline $23 \mathrm{X}-2,72-74$ & 192.03 & 1.5 & 3.035 & 0.0 & \\
\hline $25 X-2,77-79$ & 200.88 & 1.0 & ND & ND & \\
\hline $26 X-1,75-77$ & 209.65 & 5.3 & 3.034 & 0.3 & \\
\hline $26 X-3,75-77$ & 212.29 & 1.5 & ND & ND & \\
\hline
\end{tabular}


Table T2 (continued). (Continued on next page.)

\begin{tabular}{|c|c|c|c|c|c|}
\hline $\begin{array}{l}\text { Core, section, } \\
\text { interval }(\mathrm{cm})\end{array}$ & $\begin{array}{l}\text { Depth } \\
\text { (mbsf) }\end{array}$ & $\begin{array}{l}\mathrm{MCM} \\
\text { (wt\%) }\end{array}$ & $\begin{array}{l}\text { Calcite } \\
\left(\mathrm{d}_{104} \AA\right)\end{array}$ & $\begin{array}{l}\mathrm{MgCO}_{3} \\
(\mathrm{~mol} \%)\end{array}$ & Remarks \\
\hline $26 X-4,75-77$ & 213.79 & 2.3 & 3.035 & 0.0 & \\
\hline $26 X-6,75-77$ & 216.79 & 1.8 & 3.035 & 0.0 & \\
\hline $27 X-1,75-77$ & 219.25 & 3.8 & 3.034 & 0.3 & \\
\hline $27 X-2,75-77$ & 220.63 & 1.5 & ND & ND & \\
\hline $27 X-3,75-77$ & 222.04 & 1.8 & ND & ND & \\
\hline $27 X-5,75-77$ & 224.88 & 3.6 & ND & ND & \\
\hline $28 X-1,74-76$ & 228.84 & 2.3 & ND & ND & \\
\hline $28 X-2,74-76$ & 230.34 & 3.1 & 3.031 & 1.3 & \\
\hline $28 X-4,73-75$ & 232.93 & 1.3 & 3.032 & 1.0 & \\
\hline $28 X-5,68-70$ & 234.38 & 3.1 & 3.032 & 1.0 & \\
\hline $29 X-1,75-77$ & 238.45 & 3.5 & 3.032 & 1.0 & \\
\hline $29 X-3,75-77$ & 241.45 & 0.5 & ND & ND & \\
\hline $29 X-4,80-82$ & 243.00 & 2.0 & 3.028 & 2.3 & \\
\hline $29 X-5,75-77$ & 244.30 & 2.5 & ND & & \\
\hline $30 X-1,75-77$ & 248.15 & 1.5 & 3.032 & 1.0 & \\
\hline $30 X-3,73-75$ & 250.81 & 2.0 & ND & & \\
\hline $30 X-4,75-77$ & 251.86 & 0.8 & ND & ND & \\
\hline $30 X-5,70-72$ & 253.31 & 0.5 & ND & ND & \\
\hline $31 X-1,75-77$ & 257.85 & 1.0 & ND & ND & \\
\hline $31 X-2,72-74$ & 259.32 & 0.8 & ND & ND & \\
\hline $31 X-3,75-77$ & 260.85 & 1.0 & ND & ND & \\
\hline $31 X-5,75-77$ & 263.81 & 5.1 & $3.034,3.016$ & $0.3,6.4$ & \\
\hline $31 X-6,75-77$ & 265.31 & 1.5 & ND & ND & \\
\hline $32 X-1,72-74$ & 267.42 & 6.6 & 3.033 & 0.7 & \\
\hline $32 X-1,90-91$ & 267.60 & 8.1 & 3.032 & 1.0 & Abundant foraminifers in sieved fractions \\
\hline $32 X-2,75-77$ & 268.95 & 6.8 & 3.033 & 0.7 & \\
\hline $32 X-3,75-77$ & 270.45 & 6.1 & $3.035, ?$ & $0.0, ?$ & \\
\hline $32 X-5,75-77$ & 273.45 & 0.5 & ND & ND & \\
\hline $32 X-6,75-77$ & 274.95 & 0.5 & - & & \\
\hline $32 X-7,75-77$ & 275.86 & 1.0 & - & & \\
\hline $33 X-1,75-77$ & 277.05 & 2.0 & 3.032 & 1.0 & \\
\hline $33 X-2,75-77$ & 278.55 & 3.0 & 3.032 & 1.0 & \\
\hline $33 X-3,75-77$ & 280.05 & 1.5 & ND & ND & \\
\hline $33 X-5,75-77$ & 283.05 & 2.8 & 3.028 & 2.3 & \\
\hline $33 X-6,75-77$ & 284.55 & 2.0 & 3.033 & 0.7 & \\
\hline $34 X-1,73-75$ & 286.63 & 4.0 & 3.034 & 0.3 & \\
\hline $34 X-2,77-79$ & 288.17 & 7.3 & 3.032 & 1.0 & Foraminifers in sieved fractions; detrital carbonates in smearslide \\
\hline $34 X-3,77-79$ & 289.67 & 2.3 & 3.034 & 0.3 & \\
\hline $34 X-5,76-78$ & 292.66 & 4.3 & 3.033 & 0.7 & \\
\hline $34 X-6,75-77$ & 294.11 & 4.8 & 3.035 & 0.0 & \\
\hline $35 X-1,75-77$ & 296.25 & 3.0 & 3.033 & 0.7 & \\
\hline $35 X-3,75-77$ & 299.25 & 0.8 & ND & ND & \\
\hline \multicolumn{6}{|l|}{ 311-U1328B- } \\
\hline $1 \mathrm{H}-1,71-73$ & 0.71 & 8.2 & $3.034,3.005$ & $0.3,0.1$ & \\
\hline $1 \mathrm{H}-2,69-71$ & 2.19 & 3.1 & $3.034,3.002$ & $0.3,1.1$ & \\
\hline $1 \mathrm{H}-3,60-62$ & 3.60 & 2.0 & 3.027 ? & $2.7, ?$ & \\
\hline $5 \mathrm{H}-1,68-70$ & 17.18 & 3.1 & 3.035 , ? & $0.0, ?$ & \\
\hline $6 \mathrm{X}-1,36-38$ & 18.76 & 4.1 & $3.030, ?$ & $1.7, ?$ & \\
\hline $6 \mathrm{X}-1,75-77$ & 19.15 & 3.1 & $3.034, ?$ & $0.3, ?$ & \\
\hline $8 \mathrm{H}-1,75-77$ & 28.75 & 5.1 & $3.034, ?$ & $0.3, ?$ & \\
\hline $8 \mathrm{H}-2,75-77$ & 30.25 & 3.1 & 3.031,? & $1.3, ?$ & \\
\hline $8 \mathrm{H}-4,75-77$ & 33.25 & 3.1 & 3.029 & 2.0 & \\
\hline $8 \mathrm{H}-5,75-77$ & 34.75 & 2.6 & 3.029 ? & $2.0, ?$ & \\
\hline $9 \mathrm{H}-1,75-77$ & 38.25 & 6.1 & $3.033, ?$ & $0.7, ?$ & \\
\hline $9 \mathrm{H}-2,75-77$ & 39.72 & 2.6 & 3.034 & 0.3 & \\
\hline $9 \mathrm{H}-3,75-77$ & 41.06 & 4.1 & 3.033 & 0.7 & \\
\hline $9 \mathrm{H}-5,75-77$ & 44.06 & 6.1 & 3.035 & 0.0 & \\
\hline $9 \mathrm{H}-6,75-77$ & 45.56 & 9.7 & 3.034 & 0.3 & Foraminifer bloom (sieved fractions) \\
\hline $10 \mathrm{H}-1,75-77$ & 47.75 & 8.5 & 3.034 & 0.3 & \\
\hline $10 \mathrm{H}-2,75-77$ & 49.25 & 1.5 & ND & ND & \\
\hline $10 \mathrm{H}-3,75-77$ & 50.75 & 1.0 & 3.035 & 0.0 & \\
\hline $10 \mathrm{H}-5,75-77$ & 53.75 & 2.0 & 3.033 & 0.7 & \\
\hline $10 \mathrm{H}-6,75-77$ & 55.22 & 1.0 & 3.028 & 2.3 & \\
\hline \multicolumn{6}{|l|}{ 311-U1328C- } \\
\hline $1 \mathrm{H}-1,75-77$ & 57.25 & 1.0 & 3.030 & 1.7 & \\
\hline $1 \mathrm{H}-2,75-77$ & 58.71 & 1.0 & - & & \\
\hline $1 \mathrm{H}-3,75-77$ & 60.18 & 0.5 & 3.032 & 1.0 & \\
\hline $1 \mathrm{H}-4,75-77$ & 61.68 & 0.5 & 3.033 & 0.7 & \\
\hline
\end{tabular}


Table T2 (continued). (Continued on next page.)

\begin{tabular}{|c|c|c|c|c|c|}
\hline $\begin{array}{l}\text { Core, section, } \\
\text { interval }(\mathrm{cm})\end{array}$ & $\begin{array}{l}\text { Depth } \\
\text { (mbsf) }\end{array}$ & $\begin{array}{l}\text { MCM } \\
\text { (wt\%) }\end{array}$ & $\begin{array}{c}\text { Calcite } \\
\left(\mathrm{d}_{104} \AA\right)\end{array}$ & $\begin{array}{l}\mathrm{MgCO}_{3} \\
(\mathrm{~mol} \%)\end{array}$ & Remarks \\
\hline $1 \mathrm{H}-6,75-77$ & 64.68 & 1.0 & 3.031 & 1.3 & \\
\hline $2 \mathrm{H}-1,75-77$ & 66.75 & 0.5 & - & & \\
\hline $2 \mathrm{H}-2,75-77$ & 68.25 & 0.5 & - & & \\
\hline $2 \mathrm{H}-3,75-77$ & 69.75 & 1.0 & - & & \\
\hline $2 \mathrm{H}-5,75-77$ & 72.75 & 0.5 & - & & \\
\hline $3 \mathrm{H}-1,75-77$ & 76.25 & 1.5 & 3.027 & 2.7 & \\
\hline $3 \mathrm{H}-2,75-77$ & 77.75 & 1.0 & 3.032 & 1.0 & \\
\hline $3 \mathrm{H}-3,75-77$ & 79.25 & 1.0 & ND & & \\
\hline $3 \mathrm{H}-5,77-79$ & 82.27 & 2.0 & 3.029 & 2.0 & \\
\hline $3 \mathrm{H}-6,76-78$ & 83.76 & 1.0 & 3.035 & 0.0 & \\
\hline $4 X-1,75-77$ & 85.75 & 1.0 & ND & ND & \\
\hline $4 X-3,84-86$ & 88.84 & 1.0 & - & & \\
\hline $6 \mathrm{H}-1,75-77$ & 94.75 & 1.0 & ND & ND & \\
\hline $6 \mathrm{H}-2,75-77$ & 96.25 & 1.0 & 3.028 & 2.3 & \\
\hline $6 \mathrm{H}-3,75-77$ & 97.65 & 3.0 & $3.033, ?$ & $0.7, ?$ & \\
\hline $6 \mathrm{H}-6,75-77$ & 99.75 & 2.5 & 3.029 & 2.0 & \\
\hline $6 \mathrm{H}-8,75-77$ & 102.14 & 10.1 & 3.035 & 0.0 & Foraminifer bloom (sieved fractions) \\
\hline $7 X-1,73-75$ & 104.23 & 5.0 & 3.035 & 0.0 & \\
\hline $7 X-2,75-77$ & 105.75 & 5.6 & 3.034 & 0.3 & \\
\hline $7 X-4,75-77$ & 108.65 & 6.1 & 3.026 & 3.0 & \\
\hline $8 X-1,74-76$ & 111.04 & 2.0 & 3.030 & 1.7 & \\
\hline $8 X-2,74-76$ & 112.54 & 0.5 & - & & \\
\hline $8 X-4,75-77$ & 115.23 & 1.0 & 3.028 & 2.3 & \\
\hline $8 X-5,74-76$ & 116.72 & 1.0 & ND & ND & \\
\hline $8 X-6,77-79$ & 118.25 & 1.0 & ND & ND & \\
\hline $9 X-1,78-80$ & 120.68 & 1.0 & 3.027 & 2.7 & \\
\hline $9 X-4,72-74$ & 124.62 & 6.6 & 3.023 & 4.1 & No foraminifers; almost no nannoplankton but irregular carbonate grains \\
\hline $9 X-5,78-80$ & 126.18 & 1.0 & ND & ND & \\
\hline $9 \times-7,75-77$ & 128.23 & 1.0 & - & & \\
\hline $10 X-1,75-77$ & 130.35 & 1.0 & ND & ND & \\
\hline $10 X-3,75-77$ & 133.35 & 6.6 & $3.034, ?$ & $0.3, ?$ & \\
\hline $11 X-1,75-77$ & 140.05 & 4.1 & $3.033, ?$ & $0.7, ?$ & \\
\hline $11 X-2,75-77$ & 141.55 & 0.5 & 3.035 & 0.0 & \\
\hline $11 X-4,75-77$ & 144.55 & 1.0 & 3.034 & 0.3 & \\
\hline $11 X-5,73-75$ & 145.53 & 1.0 & 3.035 & 0.0 & \\
\hline $12 X-1,75-77$ & 149.65 & 3.1 & 3.035 & 0.0 & \\
\hline $12 X-2,75-77$ & 151.15 & 2.0 & 3.034 & 0.3 & \\
\hline $12 X-4,75-77$ & 154.15 & 2.5 & 3.034 & 0.3 & \\
\hline $12 X-5,75-77$ & 155.65 & 1.0 & 3.034 & 0.3 & \\
\hline $13 X-1,75-77$ & 159.35 & 1.0 & 3.032 & 1.0 & \\
\hline $13 X-2,75-77$ & 160.82 & 4.5 & 3.032 & 1.0 & \\
\hline $13 X-4,75-77$ & 163.82 & 4.5 & 3.033 & 0.7 & \\
\hline $14 X-1,75-77$ & 168.95 & 0.5 & - & & \\
\hline $14 X-2,75-77$ & 170.28 & 0.0 & - & & \\
\hline $14 X-3,75-77$ & 171.78 & 2.5 & 3.035 & 0.0 & \\
\hline $15 X-1,75-77$ & 178.65 & 0.5 & ND & ND & \\
\hline $15 X-2,75-77$ & 180.15 & 1.0 & - & & \\
\hline $15 X-3,75-77$ & 181.62 & 0.5 & - & & \\
\hline $15 X-5,75-77$ & 184.62 & 0.5 & - & & \\
\hline $16 \mathrm{X}-1,75-77$ & 188.25 & 3.5 & 3.034 & 0.3 & \\
\hline $16 \mathrm{X}-2,75-77$ & 189.75 & 5.0 & 3.035 & 0.0 & \\
\hline $16 X-5,75-77$ & 194.25 & 7.5 & 3.033 & 0.7 & \\
\hline $17 X-1,75-77$ & 197.85 & 4.0 & 3.035 & 0.0 & \\
\hline $17 X-2,75-77$ & 199.35 & 5.0 & 3.035 & 0.0 & \\
\hline $17 X-4,75-77$ & 202.35 & 6.0 & 3.035 & 0.0 & \\
\hline $17 X-5,75-77$ & 203.85 & 4.0 & 3.034 & 0.3 & \\
\hline $18 \mathrm{X}-1,62-64$ & 207.32 & 5.0 & 3.034 & 0.3 & \\
\hline $19 X-2,75-77$ & 217.78 & 8.0 & 3.035 & 0.0 & \\
\hline $19 X-4,77-79$ & 220.80 & 3.5 & 3.035 & 0.0 & \\
\hline $20 \mathrm{X}-1,75-77$ & 226.75 & 1.0 & 3.035 & 0.0 & \\
\hline $20 X-2,75-77$ & 228.25 & 4.5 & 3.034 & 0.3 & \\
\hline $20 x-3,75-77$ & 229.10 & 0.0 & - & & \\
\hline $20 X-5,75-77$ & 231.82 & 13.6 & 3.035 & 0.0 & Foraminifer bloom (sieved fractions) \\
\hline $21 X-1,75-77$ & 236.35 & 1.0 & ND & ND & \\
\hline $21 X-2,75-77$ & 237.63 & 1.0 & 3.033 & 0.7 & \\
\hline $21 X-3,75-77$ & 239.13 & 4.5 & 3.035 & 0.0 & \\
\hline $21 X-5,75-77$ & 242.13 & 1.0 & ND & ND & \\
\hline $21 X-6,75-77$ & 243.52 & 0.0 & - & & \\
\hline $22 X-1,75-77$ & 245.95 & 3.0 & 3.032 & 1.0 & \\
\hline
\end{tabular}


Table T2 (continued). (Continued on next page.)

\begin{tabular}{|c|c|c|c|c|c|}
\hline $\begin{array}{l}\text { Core, section, } \\
\text { interval }(\mathrm{cm})\end{array}$ & $\begin{array}{l}\text { Depth } \\
\text { (mbsf) }\end{array}$ & $\begin{array}{l}\text { MCM } \\
(w t \%)\end{array}$ & $\begin{array}{c}\text { Calcite } \\
\left(\mathrm{d}_{104} \AA\right)\end{array}$ & $\begin{array}{l}\mathrm{MgCO}_{3} \\
(\mathrm{~mol} \%)\end{array}$ & Remarks \\
\hline $22 X-3,75-77$ & 248.06 & 3.0 & 3.035 & 0.0 & \\
\hline $22 X-5,75-77$ & 251.06 & 2.5 & 3.035 & 0.0 & \\
\hline $22 X-6,75-77$ & 252.56 & 7.5 & 3.034 & 0.3 & \\
\hline $23 X-1,75-77$ & 255.55 & 2.5 & 3.032 & 1.0 & \\
\hline $23 X-2,75-77$ & 257.05 & 5.0 & 3.035 & 0.0 & \\
\hline $23 X-4,75-77$ & 260.05 & 1.0 & 3.032 & 1.0 & \\
\hline $24 X-1,72-74$ & 265.12 & 0.0 & - & & \\
\hline $24 X-2,75-77$ & 266.61 & 0.5 & 3.035 & 0.0 & \\
\hline $24 X-4,75-77$ & 269.47 & 0.0 & - & & \\
\hline $24 X-6,75-77$ & 271.55 & 0.0 & - & & \\
\hline $25 X-1,78-80$ & 274.88 & 0.5 & - & & \\
\hline $25 X-4,75-77$ & 279.35 & 1.0 & ND & ND & \\
\hline $25 X-5,71-73$ & 280.81 & 3.5 & 3.032 & 1.0 & \\
\hline $26 X-1,73-75$ & 284.43 & 1.0 & 3.033 & 0.7 & \\
\hline $26 X-2,73-75$ & 285.93 & 3.5 & 3.034 & 0.3 & \\
\hline $26 X-4,71-73$ & 288.91 & 1.0 & 3.031 & 1.3 & \\
\hline $26 X-5,75-77$ & 290.45 & 0.5 & 3.032 & 1.0 & \\
\hline $26 X-6,74-76$ & 291.94 & 0.5 & - & & \\
\hline $27 X-1,75-77$ & 294.05 & 2.0 & 3.035 & 0.0 & \\
\hline $27 X-2,75-77$ & 295.55 & 3.0 & 3.035 & 0.0 & \\
\hline $27 X-4,75-77$ & 298.47 & 3.0 & 3.033 & 0.7 & \\
\hline $27 X-5,75-77$ & 299.86 & 1.0 & 3.032 & 1.0 & \\
\hline \multicolumn{6}{|l|}{ 311-U1329B- } \\
\hline $1 \mathrm{H}-1,74-76$ & 0.74 & 2.8 & 3.035 & 0.0 & \\
\hline $1 \mathrm{H}-2,74-76$ & 2.24 & 1.5 & 3.035 & 0.0 & \\
\hline $1 \mathrm{H}-3,74-76$ & 3.74 & 5.8 & 3.035 & 0.0 & \\
\hline $1 \mathrm{H}-4,74-76$ & 5.24 & 7.0 & 3.035 & 0.0 & \\
\hline $1 \mathrm{H}-5,74-76$ & 6.74 & 3.8 & 3.033 & 0.7 & \\
\hline $1 \mathrm{H}-6,74-76$ & 8.24 & 3.3 & 3.031 & 1.3 & \\
\hline \multicolumn{6}{|l|}{ 311-U1329C- } \\
\hline $1 \mathrm{H}-2,75-77$ & 2.25 & 1.0 & 3.031 & 1.3 & \\
\hline $1 \mathrm{H}-4,75-77$ & 5.25 & 3.3 & 3.035 & 0.0 & \\
\hline $1 \mathrm{H}-5,75-77$ & 6.75 & 3.8 & 3.030 & 1.7 & \\
\hline $2 \mathrm{H}-2,75-77$ & 10.35 & 1.5 & 3.034 & 0.3 & \\
\hline $2 \mathrm{H}-4,75-77$ & 13.35 & 3.3 & 3.032 & 1.0 & \\
\hline $2 \mathrm{H}-5,75-77$ & 14.85 & 5.5 & 3.035 & 0.0 & \\
\hline $2 \mathrm{H}-6,77-79$ & 16.37 & 3.5 & 3.029 & 2.0 & \\
\hline $3 \mathrm{H}-1,77-79$ & 18.37 & 1.5 & 3.032 & 1.0 & \\
\hline $3 \mathrm{H}-2,75-77$ & 19.85 & 18.6 & 3.035 & 0.0 & Foraminifer bloom (sieved fractions) \\
\hline $3 \mathrm{H}-3,75-77$ & 21.35 & 6.8 & 3.033 & 0.7 & \\
\hline $3 \mathrm{H}-5,75-77$ & 24.35 & 4.3 & 3.032 & 1.0 & \\
\hline $3 \mathrm{H}-6,75-77$ & 25.85 & 0.5 & 3.029 & 2.0 & \\
\hline $4 \mathrm{H}-1,75-77$ & 27.85 & 1.3 & 3.033 & 0.7 & \\
\hline $4 \mathrm{H}-2,75-77$ & 29.35 & 3.0 & 3.031 & 1.3 & \\
\hline $4 \mathrm{H}-4,75-77$ & 32.35 & 5.5 & 3.032 & 1.0 & \\
\hline $4 \mathrm{H}-6,75-77$ & 35.35 & 3.5 & 3.032 & 1.0 & \\
\hline $4 \mathrm{H}-7,75-77$ & 36.85 & 1.0 & 3.033 & 0.7 & \\
\hline $5 \mathrm{H}-1,75-77$ & 37.35 & 5.8 & 3.024 & 3.7 & \\
\hline $5 \mathrm{H}-2,79-81$ & 38.89 & 0.8 & 3.029 & 2.0 & \\
\hline $5 \mathrm{H}-3,75-77$ & 40.35 & 0.5 & ND & ND & \\
\hline $5 \mathrm{H}-4,74-76$ & 41.84 & 0.0 & - & & \\
\hline $5 \mathrm{H}-6,74-76$ & 44.84 & 4.0 & 3.030 & 1.7 & \\
\hline $5 \mathrm{H}-7,73-75$ & 46.33 & 7.0 & 3.032 & 1.0 & \\
\hline $6 \mathrm{H}-1,75-77$ & 46.85 & 3.8 & 3.03 & 1.7 & \\
\hline $6 \mathrm{H}-2,75-77$ & 48.35 & 5.8 & 3.034 & 0.3 & \\
\hline $6 \mathrm{H}-3,75-77$ & 49.85 & 2.0 & 3.032 & 1.0 & \\
\hline $6 \mathrm{H}-4,75-77$ & 51.35 & 0.5 & ND & ND & \\
\hline $6 \mathrm{H}-6,75-77$ & 54.35 & 0.3 & - & & \\
\hline $6 \mathrm{H}-7,75-77$ & 55.85 & 0.3 & - & & \\
\hline $8 \mathrm{H}-1,75-77$ & 58.35 & 0.5 & - & & \\
\hline $8 \mathrm{H}-2,75-77$ & 59.85 & 6.8 & 3.033 & 0.7 & \\
\hline $8 \mathrm{H}-3,75-77$ & 61.35 & 4.0 & 3.033 & 0.7 & \\
\hline $8 \mathrm{H}-4,75-77$ & 62.85 & 4.0 & 3.035 & 0.0 & \\
\hline $8 \mathrm{H}-6,75-77$ & 65.85 & 9.6 & 3.035 & 0.0 & Foraminifer bloom (sieved fractions) \\
\hline $8 \mathrm{H}-7,71-73$ & 67.31 & 6.6 & 3.034 & 0.3 & \\
\hline $9 \mathrm{H}-1,75-77$ & 67.85 & 5.6 & 3.035 & 0.0 & \\
\hline $9 \mathrm{H}-2,75-77$ & 69.35 & 8.8 & 3.034 & 0.3 & \\
\hline $9 \mathrm{H}-3,75-77$ & 70.85 & 6.1 & 3.035 & 0.0 & \\
\hline
\end{tabular}


Table T2 (continued). (Continued on next page.)

\begin{tabular}{|c|c|c|c|c|c|}
\hline $\begin{array}{l}\text { Core, section, } \\
\text { interval }(\mathrm{cm})\end{array}$ & $\begin{array}{l}\text { Depth } \\
\text { (mbsf) }\end{array}$ & $\begin{array}{l}\text { MCM } \\
\text { (wt\%) }\end{array}$ & $\begin{array}{l}\text { Calcite } \\
\left(d_{104} \AA\right)\end{array}$ & $\begin{array}{l}\mathrm{MgCO}_{3} \\
(\mathrm{~mol} \%)\end{array}$ & Remarks \\
\hline $9 \mathrm{H}-4,75-77$ & 72.35 & 6.5 & 3.035 & 0.0 & \\
\hline $9 \mathrm{H}-6,75-77$ & 75.35 & 7.8 & 3.034 & 0.3 & \\
\hline $10 \mathrm{H}-1,75-77$ & 77.35 & 5.0 & 3.035 & 0.0 & \\
\hline $10 \mathrm{H}-2,75-77$ & 78.85 & 3.8 & 3.035 & 0.0 & \\
\hline $10 \mathrm{H}-3,75-77$ & 80.35 & 4.0 & 3.035 & 0.0 & \\
\hline $10 \mathrm{H}-4,75-77$ & 81.85 & 3.5 & 3.035 & 0.0 & \\
\hline $10 \mathrm{H}-6,75-77$ & 84.85 & 1.8 & 3.035 & 0.0 & \\
\hline $10 \mathrm{H}-7,75-77$ & 86.35 & 9.5 & 3.033 & 0.7 & \\
\hline $11 \mathrm{H}-1,69-71$ & 86.79 & 5.5 & 3.035 & 0.0 & \\
\hline $11 \mathrm{H}-2,75-77$ & 88.35 & 5.8 & 3.035 & 0.0 & \\
\hline $11 \mathrm{H}-3,75-77$ & 89.85 & 3.0 & 3.033 & 0.7 & \\
\hline $11 \mathrm{H}-4,75-77$ & 91.35 & 3.3 & 3.034 & 0.3 & \\
\hline $11 \mathrm{H}-6,75-77$ & 94.35 & 4.0 & 3.035 & 0.0 & \\
\hline $12 \mathrm{H}-1,75-77$ & 96.35 & 1.5 & 3.034 & 0.3 & \\
\hline $12 \mathrm{H}-2,75-77$ & 97.83 & 8.0 & 3.034 & 0.3 & \\
\hline $12 \mathrm{H}-3,75-77$ & 99.33 & 1.3 & 3.035 & 0.0 & \\
\hline $12 \mathrm{H}-4,75-77$ & 100.83 & 2.3 & 3.034 & 0.3 & \\
\hline $12 \mathrm{H}-6,75-77$ & 103.83 & 2.0 & 3.035 & 0.0 & \\
\hline $13 \mathrm{H}-1,75-77$ & 105.85 & 2.5 & 3.034 & 0.3 & \\
\hline $13 \mathrm{H}-2,91-93$ & 107.51 & 3.0 & 3.034 & 0.3 & \\
\hline $13 \mathrm{H}-3,75-77$ & 108.85 & 2.5 & 3.034 & 0.3 & \\
\hline $13 \mathrm{H}-4,75-77$ & 110.35 & 0.8 & ND & ND & \\
\hline $13 \mathrm{H}-6,37-40$ & 112.97 & 1.6 & - & & Dropstone; pyroxene-rich \\
\hline $13 \mathrm{H}-6,75-77$ & 113.35 & 0.8 & 3.035 & 0.0 & \\
\hline $13 \mathrm{H}-7,72-74$ & 114.82 & 1.3 & 3.032 & 1.0 & \\
\hline $15 \mathrm{H}-1,75-77$ & 117.35 & 0.5 & ND & ND & \\
\hline $15 \mathrm{H}-2,73-75$ & 118.83 & 0.5 & ND & ND & \\
\hline $15 \mathrm{H}-3,75-77$ & 120.35 & 0.3 & ND & ND & \\
\hline $15 \mathrm{H}-4,75-77$ & 121.85 & 0.3 & ND & ND & \\
\hline $15 \mathrm{H}-6,75-77$ & 124.85 & 1.0 & 3.032 & 1.0 & \\
\hline $15 \mathrm{H}-7,70-72$ & 126.30 & 1.3 & 3.029 & 2.0 & \\
\hline $16 \mathrm{H}-1,75-77$ & 126.85 & 8.1 & 3.035 & 0.0 & \\
\hline $16 \mathrm{H}-2,75-77$ & 128.35 & 5.1 & 3.034 & 0.3 & \\
\hline $16 \mathrm{H}-3,77-79$ & 129.87 & 1.5 & - & & \\
\hline $16 \mathrm{H}-4,75-77$ & 131.35 & 1.5 & 3.032 & 1.0 & \\
\hline $16 \mathrm{H}-6,75-77$ & 134.35 & 0.5 & - & & \\
\hline $16 \mathrm{H}-7,75-77$ & 135.85 & 3.0 & 3.015 & 6.7 & \\
\hline $17 \mathrm{H}-1,78-80$ & 136.38 & 0.5 & ND & ND & \\
\hline $17 \mathrm{H}-2,75-77$ & 137.85 & 0.3 & - & & \\
\hline $18 X-1,57-59$ & 140.77 & 0.0 & - & & \\
\hline $18 X-2,79-80$ & 142.49 & 0.0 & - & & \\
\hline $18 \times-3,57-59$ & 143.77 & 1.5 & ND & ND & \\
\hline $18 X-4,57-59$ & 145.27 & 0.5 & ND & ND & \\
\hline $19 X-1,75-77$ & 150.65 & 1.8 & 3.029 & 2.0 & \\
\hline $19 X-3,75-77$ & 153.65 & 0.8 & ND & ND & \\
\hline $19 X-4,46-48$ & 154.86 & 1.6 & 3.032 & & \\
\hline $19 X-4,75-77$ & 155.15 & 1.0 & ND & ND & \\
\hline $19 X-5,75-77$ & 156.65 & 1.0 & ND & ND & \\
\hline $20 X-1,75-77$ & 160.35 & 0.5 & - & & \\
\hline $20 X-3,75-77$ & 163.35 & 1.0 & ND & ND & \\
\hline $20 X-4,75-77$ & 164.85 & 0.5 & - & & \\
\hline $21 X-1,75-77$ & 170.05 & 2.0 & 3.019 & 5.4 & Plus traces of siderite \\
\hline $21 X-2,75-77$ & 171.55 & 1.0 & 3.030 & 1.7 & \\
\hline $21 X-3,75-77$ & 173.05 & 1.3 & ND & ND & \\
\hline $21 X-4,75-77$ & 174.55 & 1.5 & 3.033 & 0.7 & \\
\hline $22 X-1,55-57$ & 179.45 & 0.6 & - & & \\
\hline $22 X-2,55-57$ & 180.95 & 0.7 & ND & ND & \\
\hline $22 X-3,55-57$ & 182.45 & 0.6 & - & & \\
\hline $22 X-5,55-57$ & 185.42 & 1.5 & 3.032 & 1.0 & \\
\hline \multicolumn{6}{|l|}{ 311-U1329E- } \\
\hline $1 \mathrm{H}-1,75-77$ & 0.75 & 2.0 & 3.035 & 0.0 & \\
\hline $1 \mathrm{H}-2,79-81$ & 2.29 & 1.0 & 3.030 & 1.7 & \\
\hline $1 \mathrm{H}-3,75-77$ & 3.75 & 2.0 & 3.034 & 0.3 & \\
\hline $2 \mathrm{H}-1,75-77$ & 5.75 & 3.7 & 3.035 & 0.0 & \\
\hline $2 \mathrm{H}-2,75-77$ & 7.25 & 3.5 & 3.035 & 0.0 & \\
\hline $2 \mathrm{H}-3,75-77$ & 8.75 & 4.5 & 3.034 & 0.3 & \\
\hline $2 \mathrm{H}-4,75-77$ & 10.25 & 4.0 & 3.034 & 0.3 & \\
\hline $2 \mathrm{H}-5,75-77$ & 11.75 & 8.5 & 3.035 & 0.0 & \\
\hline
\end{tabular}


Table T2 (continued).

\begin{tabular}{|c|c|c|c|c|c|}
\hline $\begin{array}{l}\text { Core, section, } \\
\text { interval }(\mathrm{cm})\end{array}$ & $\begin{array}{l}\text { Depth } \\
\text { (mbsf) }\end{array}$ & $\begin{array}{l}\text { MCM } \\
\text { (wt\%) }\end{array}$ & $\begin{array}{c}\text { Calcite } \\
\left(\mathrm{d}_{104} \AA\right)\end{array}$ & $\begin{array}{l}\mathrm{MgCO}_{3} \\
(\mathrm{~mol} \%)\end{array}$ & Remarks \\
\hline $2 \mathrm{H}-6,75-77$ & 13.25 & 3.5 & 3.032 & 1.0 & \\
\hline $3 \mathrm{H}-1,75-77$ & 15.25 & 3.0 & 3.034 & 0.3 & \\
\hline $3 \mathrm{H}-2,75-77$ & 16.75 & 3.2 & 3.032 & 1.0 & \\
\hline $3 \mathrm{H}-3,75-77$ & 18.25 & 0.5 & 3.029 & 2.0 & \\
\hline $3 \mathrm{H}-4,75-77$ & 19.75 & 15.9 & 3.034 & 0.3 & Foraminifer bloom (sieved fractions) \\
\hline $3 \mathrm{H}-5,75-77$ & 21.25 & 4.7 & 3.035 & 0.0 & \\
\hline $3 \mathrm{H}-6,75-77$ & 22.75 & 3.7 & 3.035 & 0.0 & \\
\hline $4 \mathrm{H}-1,75-77$ & 24.75 & 1.0 & 3.028 & 2.3 & \\
\hline $4 \mathrm{H}-2,75-77$ & 26.25 & 1.0 & 3.033 & 0.7 & \\
\hline $4 \mathrm{H}-3,78-80$ & 27.78 & 6.0 & 3.030 & 1.7 & \\
\hline $4 \mathrm{H}-4,74-76$ & 29.24 & 6.0 & 3.033 & 0.7 & \\
\hline $4 \mathrm{H}-5,75-77$ & 30.75 & 6.5 & 3.035 & 0.0 & \\
\hline
\end{tabular}

Notes: Dolomite present but not reported. $\mathrm{MCM}=$ ManoCalcimeter Mélières apparatus. ND = present but not determined, $-=$ absent or below detection level, bold = higher carbonate values (nature of carbonate observed in smear slide or sieved fractions and reported in Remarks column). 


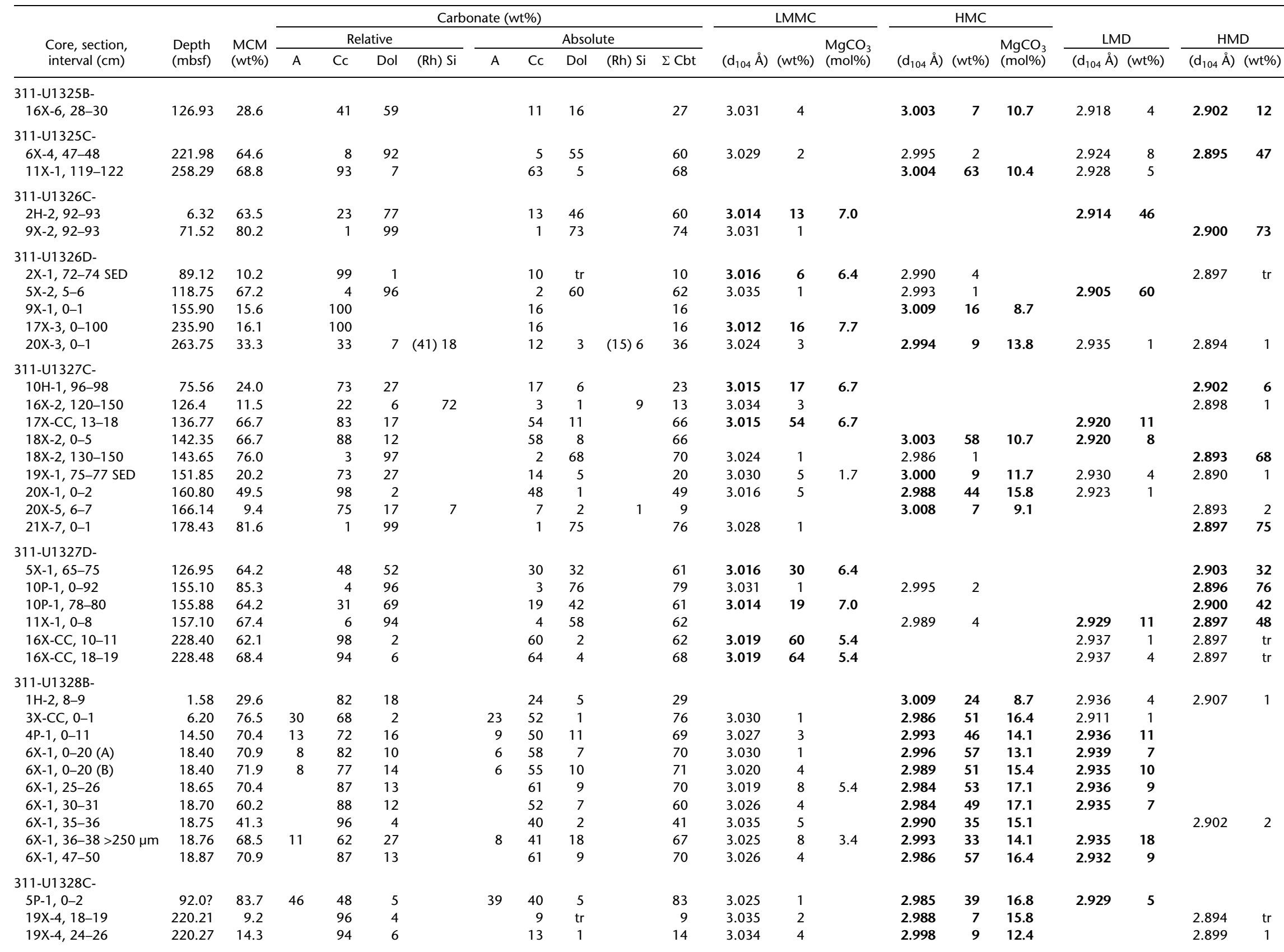


Table T3 (continued). (Continued on next page.)

\begin{tabular}{|c|c|c|c|c|c|c|c|c|c|c|c|c|c|c|c|c|c|c|c|c|c|}
\hline \multirow{3}{*}{$\begin{array}{l}\text { Core, section, } \\
\text { interval }(\mathrm{cm})\end{array}$} & \multirow{3}{*}{$\begin{array}{l}\text { Depth } \\
\text { (mbsf) }\end{array}$} & \multirow{3}{*}{$\begin{array}{l}\text { MCM } \\
\text { (wt\%) }\end{array}$} & \multicolumn{9}{|c|}{ Carbonate (wt\%) } & \multicolumn{3}{|c|}{ LMMC } & \multicolumn{3}{|c|}{$\mathrm{HMC}$} & \multirow{2}{*}{\multicolumn{2}{|c|}{ LMD }} & \multirow{2}{*}{\multicolumn{2}{|c|}{ HMD }} \\
\hline & & & \multicolumn{4}{|c|}{ Relative } & \multicolumn{5}{|c|}{ Absolute } & \multirow[b]{2}{*}{$\left(d_{104} \AA\right)$} & \multirow[b]{2}{*}{ (wt\%) } & \multirow{2}{*}{$\begin{array}{l}\mathrm{MgCO}_{3} \\
(\mathrm{~mol} \%)\end{array}$} & & & $\mathrm{MgCO}_{3}$ & & & & \\
\hline & & & $A$ & $\mathrm{Cc}$ & Dol & $(\mathrm{Rh}) \mathrm{Si}$ & $A$ & $\mathrm{Cc}$ & Dol & (Rh) $\mathrm{Si}$ & $\Sigma \mathrm{Cbt}$ & & & & $\left(d_{104} \AA\right)$ & (wt\%) & (mol\%) & $\left(d_{104} \AA\right)$ & $(w t \%)$ & $\left(\mathrm{d}_{104} \AA\right)$ & (wt\%) \\
\hline $19 X-4,26-28$ & 220.29 & 50.0 & & 80 & 20 & & & 39 & 10 & & 49 & 3.023 & 8 & 4.0 & 2.987 & 31 & 16.1 & 2.935 & 10 & & \\
\hline $19 X-4,32-36$ & 220.35 & 58.2 & & 92 & 8 & & & 53 & 5 & & 58 & 3.016 & 2 & & 2.998 & 51 & 12.4 & 2.935 & 5 & & \\
\hline $22 \mathrm{X}-\mathrm{CC}, 12-14$ & 253.70 & 78.6 & & & 100 & & & & 72 & & 72 & & & & & & & & & 2.887 & 72 \\
\hline $22 \mathrm{X}-\mathrm{CC}, 20-21$ & 253.78 & 36.2 & & 13 & 87 & & & 4 & 29 & & 34 & 3.034 & 4 & & 2.990 & 1 & & & & 2.888 & 29 \\
\hline $22 \mathrm{X}-\mathrm{CC}, 20-22$ & 253.78 & 71.4 & & 2 & 98 & & & 2 & 64 & & 66 & 3.032 & 2 & & & & & & & 2.890 & 64 \\
\hline $25 X-2,77-79$ & 276.37 & 59.2 & & 3 & 97 & & & 2 & 53 & & 55 & 3.034 & $\operatorname{tr}$ & & 2.992 & 1 & & & & 2.895 & 53 \\
\hline 311-U1328D- & & & & & & & & & & & & & & & & & & & & & \\
\hline $1 X-2,40-42$ & $1.90 ?$ & 31.1 & & 91 & 9 & & & 28 & 3 & & 31 & 3.030 & 3 & & 2.994 & 25 & 13.8 & 2.937 & 2 & 2.904 & 1 \\
\hline $1 X-5,9-11$ & $6.09 ?$ & 43.4 & & 97 & 3 & & & 42 & 1 & & 43 & 3.025 & 3 & & 2.992 & 39 & 14.4 & 2.925 & 1 & 2.901 & 1 \\
\hline $1 X-5,10-11$ & $6.10 ?$ & 50.0 & & 97 & 3 & & & 48 & 1 & & 50 & 3.030 & 4 & & 2.993 & 45 & 14.1 & 2.911 & 1 & & \\
\hline $1 X-5,135-150$ & $7.35 ?$ & 83.7 & & 81 & 19 & & & 66 & 16 & & 82 & & & & 2.989 & 66 & 15.4 & & & 2.902 & 16 \\
\hline $1 \mathrm{X}-\mathrm{CC}, 0-5$ & $8.10 ?$ & 39.8 & & 27 & 73 & & & 10 & 27 & & 37 & 3.032 & 4 & & 2.993 & 7 & 14.1 & & & 2.895 & 27 \\
\hline $2 X-2,30-31$ & $5.80 ?$ & 67.9 & & 30 & 70 & & & 19 & 45 & & 64 & & & & 2.988 & 19 & 15.8 & 2.916 & 23 & 2.894 & 22 \\
\hline $2 \mathrm{X}-\mathrm{CC}, 0-5$ & $6.29 ?$ & 60.7 & & 8 & 92 & & & 4 & 52 & & 56 & 3.032 & 2 & & 2.999 & 2 & & & & 2.904 & 52 \\
\hline 311-U1328E- & & & & & & & & & & & & & & & & & & & & & \\
\hline $2 X-1,52-54$ & 7.02 & 70.4 & & 100 & & & & 70 & & & 70 & & & & 3.001 & 70 & 11.4 & & & & \\
\hline $8 X-1,57-58$ & 27.27 & 71.4 & & 93 & 7 & & & 66 & 5 & & 71 & 3.030 & 1 & & 2.989 & 65 & 15.4 & 2.935 & 5 & & \\
\hline $8 X-1,97-98$ & 27.67 & 67.3 & & 96 & 4 & & & 64 & 3 & & 67 & & & & 2.990 & 64 & 15.1 & 2.931 & 2 & 2.897 & $\operatorname{tr}$ \\
\hline $9 X-1,16-17$ & 36.46 & 68.4 & & 85 & 15 & & & 57 & 10 & & 67 & & & & 2.989 & 57 & 15.4 & 2.927 & 10 & & \\
\hline 311-U1329C- & & & & & & & & & & & & & & & & & & & & & \\
\hline $4 \mathrm{H}-3,138-140$ & 31.48 & 34.6 & & & 100 & & & & 32 & & 32 & & & & & & & 2.922 & 13 & 2.898 & 19 \\
\hline $4 \mathrm{H}-3,140-142$ & 31.50 & 58.6 & & & 100 & & & & 54 & & 54 & & & & & & & 2.923 & 22 & 2.897 & 32 \\
\hline $5 \mathrm{H}-3,129-131$ & 40.89 & 14.7 & & 100 & & & & 15 & & & 15 & 3.018 & 12 & 5.7 & 2.991 & 3 & & & & & \\
\hline $5 \mathrm{H}-6,61-62$ & 44.71 & 26.2 & & 30 & 70 & & & 7 & 17 & & 25 & 3.035 & 4 & & 2.999 & 3 & & 2.931 & 2 & 2.905 & 15 \\
\hline $8 \mathrm{H}-2,58-60$ & 59.68 & 79.6 & & 100 & & & & 80 & & & 80 & & & & 2.993 & 80 & 14.1 & & & & \\
\hline $8 \mathrm{H}-2,62-64$ & 59.72 & 53.9 & & 100 & & & & 54 & & & 54 & & & & 2.995 & 54 & 13.4 & & & & \\
\hline $8 \mathrm{H}-2,91-93$ & 60.01 & 7.9 & & 95 & 5 & & & 7 & $\operatorname{tr}$ & & 8 & 3.035 & 3 & & 2.996 & 5 & 13.1 & & & 2.893 & $\operatorname{tr}$ \\
\hline $12 \mathrm{H}-2,36-37$ & 97.44 & 27.7 & & 67 & 33 & & & 18 & 9 & & 27 & 3.024 & 2 & & 2.995 & 16 & 13.4 & 2.933 & 7 & 2.907 & 2 \\
\hline $17 \mathrm{H}-1,0-2$ & 135.60 & 67.6 & & 90 & 10 & & & 60 & 7 & & 67 & 3.031 & 23 & 1.3 & 3.004 & 37 & 10.4 & 2.944 & 5 & 2.913 & 1 \\
\hline $18 X-2,65-66$ & 142.35 & 75.9 & & 45 & 55 & & & 33 & 40 & & 72 & 3.016 & 33 & 6.4 & & & & 2.928 & 6 & 2.900 & 40 \\
\hline $18 X-2,69-71$ & 142.39 & 3.7 & & 10 & 90 & & & $\operatorname{tr}$ & 3 & & 3 & $3.028 ?$ & $\mathrm{tr}$ & & & & & & & 2.900 & 3 \\
\hline $18 X-5,18-20$ & 146.38 & 89.0 & & & 100 & & & & 82 & & 82 & & & & & & & & & 2.897 & 82 \\
\hline $18 X-5,27-29$ & 146.47 & 80.6 & & & 100 & & & & 74 & & 74 & & & & & & & & & 2.895 & 74 \\
\hline $19 X-1,64-66$ & 150.54 & 33.0 & & 7 & & 93 & & 3 & & 35 & 38 & 3.027 & 3 & & & & & & & & \\
\hline $20 \mathrm{X}-1,70-71$ & 160.30 & 78.0 & & 100 & & & & 78 & & & 78 & & & & 3.000 & 78 & 11.7 & & & & \\
\hline $20 X-1,89-90$ & 160.49 & 79.6 & & 100 & & & & 80 & & & 80 & & & & 3.000 & 80 & 11.7 & & & & \\
\hline $20 X-1,125-126$ & 160.85 & 81.7 & & 100 & & & & 82 & & & 82 & & & & 2.997 & 82 & 12.8 & & & & \\
\hline $20 X-3,34-36$ & 162.94 & 80.6 & & 100 & & & & 81 & & & 81 & & & & 2.995 & 81 & 13.4 & & & & \\
\hline $20 X-5,34-35$ & 165.44 & 69.6 & & 100 & & & & 70 & & & 70 & & & & 2.996 & 70 & 13.1 & & & & \\
\hline $20 \mathrm{X}-\mathrm{CC}, 19-20$ & 166.00 & 83.2 & & & 100 & & & & 77 & & 77 & & & & & & & & & 2.896 & 77 \\
\hline $21 X-2,118-120$ & 171.98 & 44.0 & & 36 & 8 & 56 & & 17 & 4 & 26 & 47 & 3.013 & 17 & 7.4 & & & & & & 2.929 & 4 \\
\hline $21 X-3,61-63 A$ & 172.91 & 49.2 & & 96 & & 4 & & 48 & & 2 & 49 & 3.019 & 48 & 5.4 & & & & & & & \\
\hline $21 X-3,61-63 B$ & 172.91 & 52.9 & & 100 & & & & 53 & & & 53 & 3.017 & 53 & 6.0 & & & & & & & \\
\hline $21 X-3,61-63$ SED & 172.91 & 51.0 & & 100 & & & & 51 & & & 51 & 3.017 & 51 & 6.0 & & & & & & & \\
\hline $21 X-3,129-131$ & 173.59 & 16.2 & & 38 & & 62 & & 7 & & 11 & 18 & 3.011 & 7 & 8.1 & & & & & & & \\
\hline $21 \mathrm{X}-3,129-131$ Bis & 173.59 & 63.5 & & 18 & & 82 & & 13 & & 58 & 71 & 3.014 & 13 & 7.0 & & & & & & & \\
\hline $21 \mathrm{X}-6,0-30$ & 176.30 & 81.7 & & 1 & 99 & & & 1 & 74 & & 75 & 3.033 & 1 & & & & & & & 2.894 & 74 \\
\hline $22 \mathrm{X}-\mathrm{CC}, 72-74$ & 187.75 & 60.3 & & 100 & & & & 60 & & & 60 & 3.028 & 60 & 2.3 & & & & & & & \\
\hline
\end{tabular}


Table T3 (continued).

\begin{tabular}{|c|c|c|c|c|c|c|c|c|c|c|c|c|c|c|c|c|c|c|c|c|c|}
\hline \multirow{3}{*}{$\begin{array}{l}\text { Core, section, } \\
\text { interval }(\mathrm{cm})\end{array}$} & \multirow{3}{*}{$\begin{array}{l}\text { Depth } \\
\text { (mbsf) }\end{array}$} & \multirow{3}{*}{$\begin{array}{l}\text { MCM } \\
\text { (wt\%) }\end{array}$} & \multicolumn{9}{|c|}{ Carbonate (wt\%) } & \multicolumn{3}{|c|}{ LMMC } & \multicolumn{3}{|c|}{ HMC } & \multirow{2}{*}{\multicolumn{2}{|c|}{ LMD }} & \multirow{2}{*}{\multicolumn{2}{|c|}{ HMD }} \\
\hline & & & \multicolumn{4}{|c|}{ Relative } & \multicolumn{5}{|c|}{ Absolute } & \multirow[b]{2}{*}{$\left(d_{104} \AA\right)$} & \multirow[b]{2}{*}{ (wt\%) } & \multirow{2}{*}{$\begin{array}{l}\mathrm{MgCO}_{3} \\
(\mathrm{~mol} \%)\end{array}$} & \multirow[b]{2}{*}{$\left(\mathrm{d}_{104} \AA\right)$} & \multirow[b]{2}{*}{ (wt\%) } & \multirow{2}{*}{$\begin{array}{l}\mathrm{MgCO}_{3} \\
(\mathrm{~mol} \%)\end{array}$} & & & & \\
\hline & & & $\mathrm{A}$ & $\mathrm{Cc}$ & Dol & $(\mathrm{Rh}) \mathrm{Si}$ & $\mathrm{A}$ & $\mathrm{Cc}$ & Dol & $(\mathrm{Rh}) \mathrm{Si}$ & $\Sigma \mathrm{Cbt}$ & & & & & & & $\left(d_{104} \AA\right)$ & $(w t \%)$ & \multicolumn{2}{|c|}{$\left(d_{104} \AA\right) \quad(w t \%)$} \\
\hline \multicolumn{22}{|l|}{ 311-U1329E- } \\
\hline $4 \mathrm{H}-5,48-50$ & 30.48 & 67.5 & & 11 & 89 & & & 7 & 56 & & 63 & 3.031 & 7 & 1.3 & & & & 2.926 & 4 & 2.902 & 52 \\
\hline $4 \mathrm{H}-5,93-95$ & 30.93 & 35.6 & & 10 & 90 & & & 3 & 30 & & 33 & 3.033 & 3 & & & & & 2.923 & 5 & 2.899 & 25 \\
\hline $4 \mathrm{H}-5,113-118$ & 31.13 & 70.1 & & 1 & 99 & & & 1 & 64 & & 65 & 3.033 & 1 & & & & & 2.929 & 7 & 2.901 & 57 \\
\hline $4 \mathrm{H}-6,72-74$ SED & 32.22 & 42.5 & & 5 & 95 & & & 2 & 37 & & 39 & & & & 2.988 & 2 & & 2.926 & 4 & 2.898 & 33 \\
\hline $8 Y-1,35-37$ & 104.35 & 63.9 & & & 100 & & & & 59 & & 59 & & & & & & & & & 2.894 & 59 \\
\hline
\end{tabular}

Notes: $\mathrm{MCM}=$ ManoCalcimeter Mélières apparatus, $\mathrm{A}=$ aragonite, $\mathrm{Cc}=$ calcite, Dol = dolomite, Rh = "rhodochrosite" $\left(\mathrm{d}_{104} \approx 2.85 \AA\right.$ ), $\mathrm{Si}=$ "siderite" $\left(\mathrm{d}_{104} \approx 2.796 \AA\right.$ A $), \mathrm{LMMC}=$ low- to mediummagnesium calcite, $\mathrm{HMC}=$ high-magnesium calcite, $\mathrm{LMD}=$ low-magnesium dolomite, HMD = high-magnesium dolomite. SED = standard sediment sample, Bis = more carbonated part of the sample. ? = dubious depth value, bold = most significant values, $\mathrm{tr}=$ traces. For distinction between LMMC, HMC, LMD, and HMC from frequency distribution of $\mathrm{d}_{104}$, see Figure F1. $\mathrm{MgCO}_{3} \mathrm{~mol} \%$ not reported when calcite weight percent was too low. 